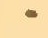


NBS

Publi -

cations

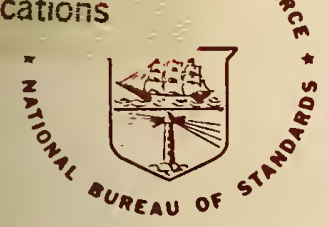

\section{AN EVALUATION OF COMMERCIAL DENSIMETERS FOR USE IN LNG}




\section{NATIONAL BUREAU OF STANDARDS}

The National Bureau of Standards ${ }^{1}$ was established by an act of Congress March 3, 1901. The Bureau's overall goal is to strengthen and advance the Nation's science and technology and facilitate their effective application for public benefit. To this end, the Bureau conducts research and provides: (1) a basis for the Nation's physical measurement system, (2) scientific and technological services for industry and government, (3) a technical basis for equity in trade, and (4) technical services to promote public safety. The Bureau consists of the Institute for Basic Standards, the Institute for Materials Research, the Institute for Applied Technology, the Institute for Computer Sciences and Technology, the Office for Information Programs, and the Office of Experimental Technology Incentives Program.

THE INSTITUTE FOR BASIC STANDARDS provides the central basis within the United States of a complete and consistent system of physical measurement; coordinates that system with measurement systems of other nations; and furnishes essential services leading to accurate and uniform physical measurements throughout the Nation's scientific community, industry, and commerce. The Institute consists of the Office of Measurement Services, and the following center and divisions:

Applied Mathematics - Electricity - Mechanics - Heat - Optical Physics - Center for Radiation Research - Laboratory Astrophysics ${ }^{2}$ - Cryogenics ${ }^{2}$ - Electromagnetics ${ }^{2}$ - Time and Frequency ${ }^{2}$.

THE INSTITUTE FOR MATERIALS RESEARCH conducts materials research leading to improved methods of measurement, standards, and data on the properties of well-characterized materials needed by industry, commerce, educational institutions, and Government; provides advisory and research services to other Government agencies; and develops, produces, and distributes standard reference materials. The Institute consists of the Office of Standard Reference Materials, the Office of Air and Water Measurement, and the following divisions:

Analytical Chemistry - Polymers - Metallurgy - Inorganic Materials - Reactor Radiation - Physical Chemistry.

THE INSTITUTE FOR APPLIED TECHNOLOGY provides technical services developing and promoting the use of available technology; cooperates with public and private organizations in developing technological standards, codes, and test methods; and provides technical advice services, and information to Government agencies and the public. The Institute consists of the following divisions and centers:

Standards Application and Analysis - Electronic Technology - Center for Consumer Product Technology: Product Systems Analysis; Product Engineering - Center for Building Technology: Structures, Materials, and Safety; Building Environment; Technical Evaluation and Application - Center for Fire Research: Fire Science; Fire Safety Engineering.

THE INSTITUTE FOR COMPUTER SCIENCES AND TECHNOLOGY conducts research and provides technical services designed to aid Government agencies in improving cost effectiveness in the conduct of their programs through the selection, acquisition, and effective utilization of automatic data processing equipment: and serves as the principal focus wthin the executive branch for the development of Federal standards for automatic data processing equipment, techniques, and computer languages. The Institute consist of the following divisions:

Computer Services - Systems and Software - Computer Systems Engineering — Information Technology.

THE OFFICE OF EXPERIMENTAL TECHNOLOGY INCENTIVES PROGRAM seeks to affect public policy and process to facilitate technological change in the private sector by examining and experimenting with Government policies and practices in order to identify and remove Government-related barriers and to correct inherent market imperfections that impede the innovation process.

THE OFFICE FOR INFORMATION PROGRAMS promotes optimum dissemination and accessibility of scientific information generated within NBS: promotes the development of the National Standard Reference Data System and a system of information analysis centers dealing with the broader aspects of the National Measurement System; provides appropriate services to ensure that the NBS staff has optimum accessibility to the scientific information of the world. The Office consists of the following organizational units:

Office of Standard Reference Data - Office of Information Activities — Office of Technical Publications - Library Office of International Standards - Office of International Relations.

${ }^{1}$ Headquarters and Laboratories at Gaithersburg, Maryland, unless otherwise noted; mailing address Washington, D.C. 20234.

2 Located at Bouider, Colorado 80302. 
NATIONAT BUREAO

OF STANDARDS

IIBRARY

FEB $8 \quad 1978$

rot occ-Rey

\section{AN EVALUATION OF}

COMMERCIAL DENSIMETERS

FOR USE IN LNG

J.D. Siegwarth and B.A. Younglove

Cryogenics Division

Institute for Basic Standards

National Bureau of Standards

Boulder, CO 80302

and

J.F. LaBrecque

Applied Mathematics Division Institute for Basic Standards

National Bureau of Standards

Boulder, CO 80302

Prepared for

American Gas Association, Inc.

1515 Wilson Boulevard

Arlington, VA 22209

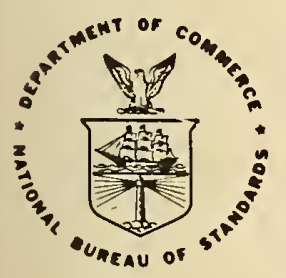

U.S. DEPARTMENT OF COMMERCE, Juanita M. Kreps, Secretary

Sidney Harman, Under Secretary

Jordan J. Baruch, Assistant Secretary for Science and Technology

S. NATIONAL BUREAU OF STANDARDS, Ernest Ambler, Acting Director 
NATIONAL BUREAU OF STANDARDS TECHNICAL NOTE 697

Nat. Bur. Stand. (U.S.), Tech. Note 697, 52 pages (October 1977)

CODEN: NBTNAE

U.S. GOVERNMENT PRINTING OFFICE

WASHINGTON: 1977

For sale by the Superintendent of Documents, U.S. Government Printing Office, Washington, D.C. 20402

Stock No.003-003-018627 Price $\$ 2.20$ (Add 25 percent additional for other than U.S. mailing) 
1. INTRODUCTION . . . . . . . . . . . . . . . . . . . 1

2. THE DENSITY REFERENCE SYSTEM . • . . • . . . . . . . . . . . . . 1

3. DENSTMETERS . . . . . . . . . . . . . . . . . . . . 3

3.1. Vibrating Element Densimeter . . . . . . . . . . . 3

3.2 Dielectric Cell Densimeter . . . . . . . . . . . . . . 4

3.3 Displacement or Archimedes Densimeter . . . . . . . . . . 4

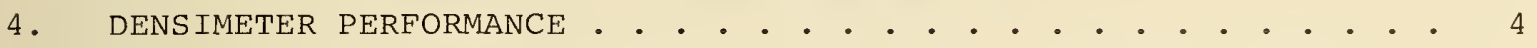

4.1. Comparison of Haynes-Hiza and Density Reference System

Density Determinations . . . . . . . . . . . . . . . 7

4.2. The Vibrating Cylinder Densimeter . . . . . . . . . . . 11

4.3. Vibrating Plate Densimeter . . . . . . . . . . . . 19

4.4. Capacitance or Dielectric Type Densimeter . . . . . . . . 27

4.5. The Displacement Densimeter . . . . . . . . . . . . 35

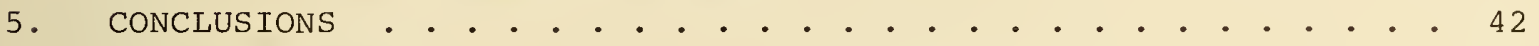

6. ACKNOWLEDGMENTS . . . . . . . . . . . . . . . . . . 4 42

7. REFERENCES . . . . . . . . . . . . . . . . . . . . . 43

8. APPENDIX I . . . . . . . . . . . . . . . . . . . . . 44 

The cryogenic fluids density reference system has been used to evaluate three basic types of densimeters: the vibrating element type, the dielectric cell type and the displacement type. These meters were used to measure densities in liquid methane and liquid methane mixtures with ethane, propane, normal butane, and nitrogen. Measurements were made over the density range from 400 to $480 \mathrm{~kg} / \mathrm{m}^{3}$, temperatures from $108 \mathrm{~K}$ to $130 \mathrm{~K}$, and pressures from 1 to $3 \mathrm{bar}$. A hundred measurements were made at various densities, temperatures, pressures and compositions.

Key words: Cryogenic densimeters; density reference system; liquid methane; LNG.

\section{INTRODUCTION}

The density reference system (DRS) provides a well-characterized sample of a cryogenic fluid such as liquefied natural gas (LNG) and related mixtures in which densimeters can be placed for evaluation. The DRS measures liquid density, temperature and pressure.

Densities varying from 400 to $480 \mathrm{~kg} / \mathrm{m}^{3}$ have been determined from the apparent mass of a silicon single crystal weighed in the liquid by an automatic balance. Temperature is calculated from vapor pressure thermometers filled with methane whose pressure is measured with a quartz-spiral bourdon gauge.

Mixtures were made from laboratory grade (99.97 to 99.99 mol \%) methane, ethane, propane, n-butane and nitrogen.

Three basic types of densimeters were studied: the vibrating element type, the dielectric cell type and the displacement type.

\section{THE DENSITY REFERENCE SYSTEM}

The density reference system is designed to compare other densimeters to an accurate Archimedes type densimeter in an isothermal liquid. The accuracy of this reference densimeter is discussed in a separate report [1].

The liquid sample, test densimeters, and other measuring devices are contained in a closed system, as shown in figure 1. An automatic balance is in an upper gas space which is an integral part of the sample space. From the balance arm is suspended a silicon single crystal, whose apparent mass 


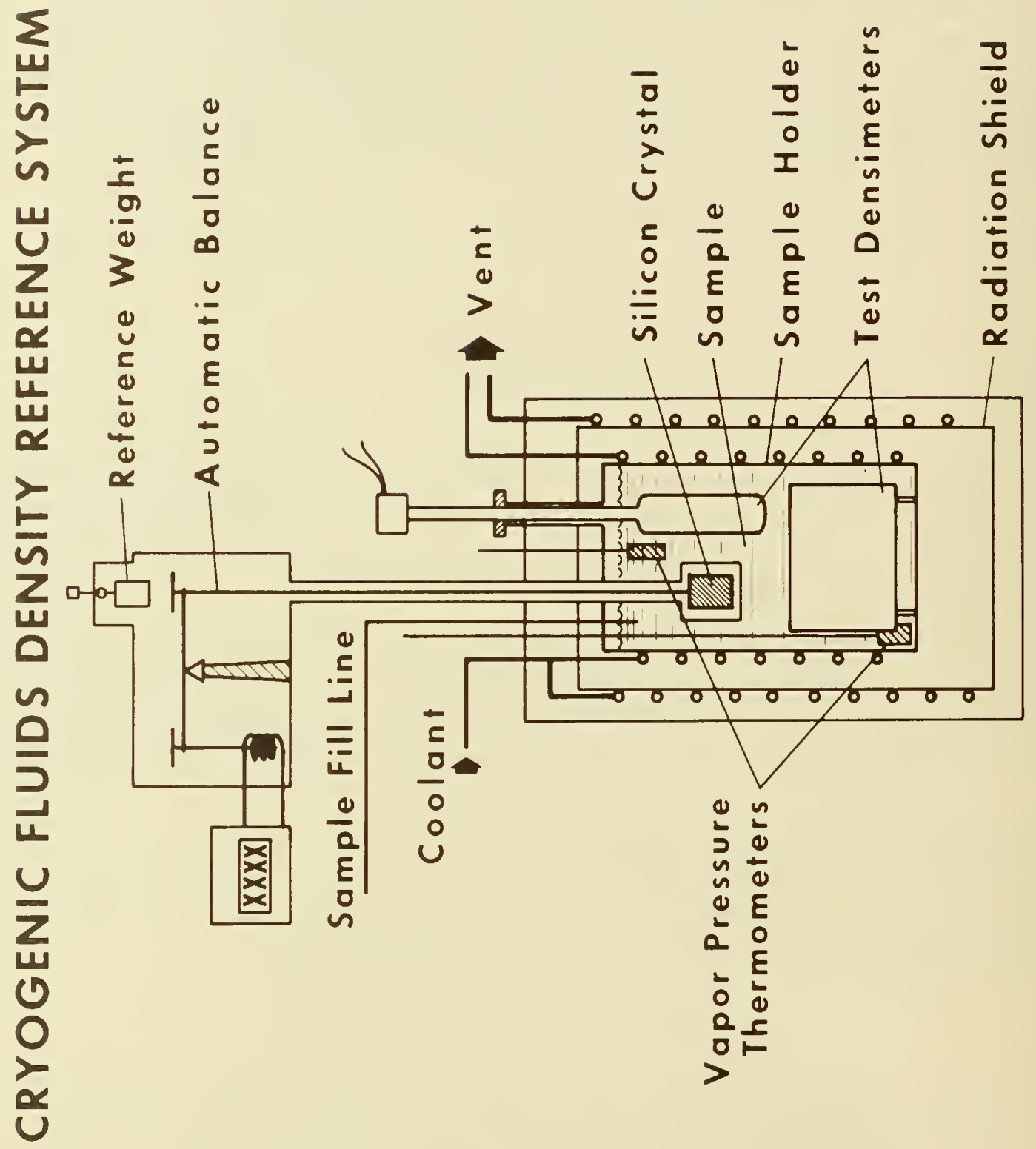


when immersed in the liquid is directly related to the liquid density. Two vapor pressure thermometers measure the liquid temperature at the top and bottom of the sample [1]. Pressure of the liquid sample is measured by a quartz-spiral bourdon gauge.

Cryogenic temperatures are achieved by flowing cold nitrogen gas through a coiled tube attached to the outside of the sample holder. These coils were used to cool the sample, and electric heaters, also wound on the sample holder, were used to heat it when changing temperatures between data points. Each data point was taken with the sample and container very close to isothermal conditions. During the period of time data was being recorded, the heat capacity of the sample was used to keep the temperature constant. The heat leak to the sample was minimized by surrounding the sample cell with a nitrogen gas cooled shield. The shield temperature was maintained near that of the sample by controlling the flow of the nitrogen gas passing through the shield cooling coil. To obtain temperature equilibrium rapidly in the 14 liter vessel, a $5 \mathrm{~cm}$ diameter turbine pump is used to $\mathrm{mix}$ the sample. The sample fluid is pumped through a $3.5 \mathrm{~cm}$ diameter intake line from the bottom of the sample vessel and is exhausted into the top of the vessel through a discharge line of the same size. This stirrer is capable of mixing the fluid very rapidly at full speed. The speed of the pump has to be reduced considerably during the actual measurements since rapid circulation of fluid sample affected the readings of the densimeters under test. A low stirring rate, which did not affect the instruments, was used during the measurement to maintain an isothermal sample.

The density variation in the sample holder was evaluated from the vapor pressure thermometer measurements. The temperatures at the top and bottom of the sample holder were computed from the vapor pressure equation of Goodwin [2]. From the average of the temperatures, the density of liquid methane was calculated according to the work of Haynes and Hiza [3]. The Haynes-Hiza (HH) measurements agree with the density correlations of Goodwin [2] to within the estimated uncertainty of both. Since the HH and the DRS densimeters are both Archimedes types [4], the DRS has been compared to the HH results directly. The density differences between the top and bottom of the sample holder have been less than $0.04 \%$.

\section{DENSIMETERS}

\subsection{Vibrating Element Densimeter}

The basic principle relating density to frequency is directly equivalent to the classical mass and spring oscillator. The vibrating member of the densimeter, a rectangular plate in one instance and a vibrating cylinder in the other instance, has a natural frequency determined by the stiffness 
constant and apparent mass of the vibrating element. The apparent mass of the element depends on the density of the fluid surrounding it since in vibration a portion of this liquid is also forced to move. The density, $\rho$, is related to the period of oscillation, $\tau$, by

$$
\rho=\mathrm{A}+\mathrm{B} \tau^{2}
$$

$A$ and $B$ are constants determined empirically at cryogenic temperatures.

3.2 Dielectric Cell Densimeter

The Clausius-Mossotti relation [5] is

$$
\rho=(\varepsilon-1) /(\varepsilon+2) \alpha,
$$

where $\varepsilon$ is dielectric constant and $\alpha$ is the polarizability, generally taken to be a constant, independent of density.

Over a limited range of composition, however, the density can be represented by a linear function of the temperature and dielectric constant [5] rather than equation (2). This linear relation can be used along the saturation line of the fluid. The densimeter studied in this work uses a bilinear relation to relate dielectric constant and temperature to density.

\subsection{Displacement or Archimedes Densimeter}

The operation of this densimeter is based on the Archimedes principle; that is, an object immersed in a still fluid experiences a lifting force equal to the weight of the fluid it displaces.

The measurement equation for this device is

$$
\rho=\rho_{0}\left(M-M_{a}\right) / M
$$

where $\rho_{0}$ is the density of the submerged object and $M$ its mass. $M_{a}$ is its apparent mass. The two unknowns $\rho_{0}$ and $M$ are determined for this instrument by calibration at two or more well defined densities.

\section{DENSIMETER PERFORMANCE}

Each densimeter was compared to the DRS. As an independent check on the DRS measurement, the density of saturated liquid methane was calculated from the average temperature and then compared with the density measured with the DRS. There were six fillings of the system, five using methane and one with an LNG-like mixture without nitrogen. Nitrogen was later added to two of the methane fillings and the LNG mixture. These liquids are listed 
in Table I. The symbols in this table appear in all the following figures showing the pure methane and mixtures together.

The LNG mixture contained approximately $88-1 / 2 \% \mathrm{CH}_{4}, 6-1 / 2 \% \mathrm{C}_{2} \mathrm{H}_{6}$, 3 응 $\mathrm{C}_{3} \mathrm{H}_{8}$ and $2 \% \mathrm{n}-\mathrm{C}_{4} \mathrm{H}_{10}$.

Table I.

\section{Symbol}

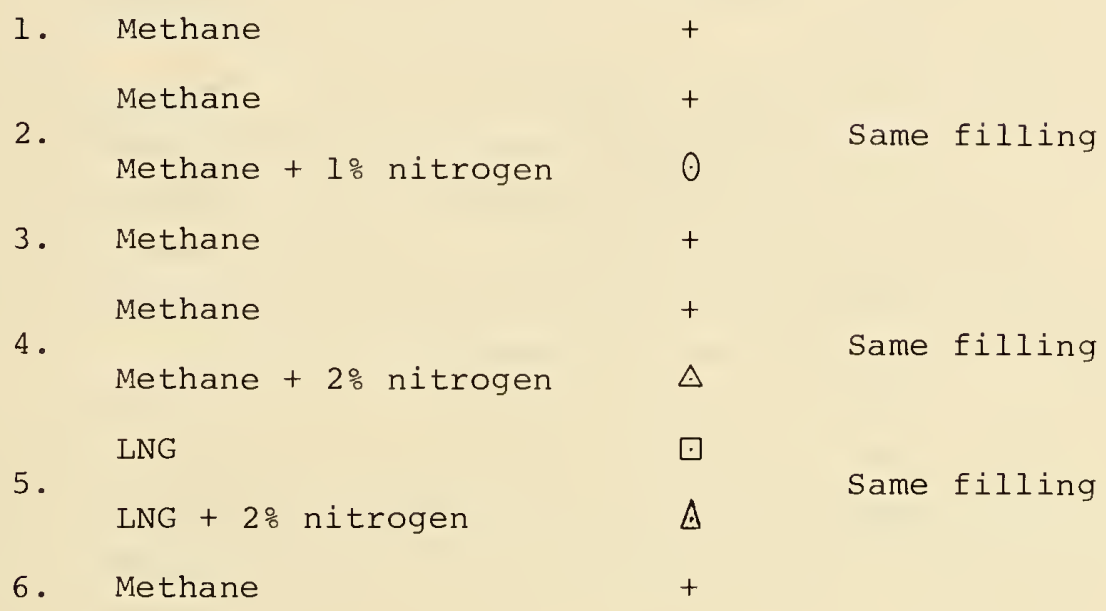

Two types of data are considered in this section:

1. differences, $x_{i}-$ DRS $_{i}$ '

where $x_{i}$ is a density determination by one of the test densimeters and $\mathrm{DRS}_{i}$ is the corresponding DRS value, and

2. percentage difference, $100 \%\left(x_{i}-D^{2} S_{i}\right) / D R S_{i}$.

Plots are of the percentage difference data only.

Four plots of the percentage differences are provided for each of the densimeter comparisons: methane data in chronological order and versus density (different symbols used for each filling), and all data in chronological order and versus density (symbols given in Table l). The detailed analysis of the data shown in the figures is described below.

If the DRS and the densimeter under test give the same density except for random error, then the differences $x_{i}-D_{i}$ for repeated density measurements will tend to cluster about zero. In this case the densimeter is said to be relatively accurate with respect to the DRS. However, experience has shown that the differences often show an average value that is not zero. In addition, this average value may be density or temperature dependent. This average value may also vary randomly with time or from filling to filling.

In order to include all the above possibilities, the model used for comparing densimeters to the DRS is 


$$
x_{i j k}-D_{i j k}=m+s\left(D_{i}-\bar{D}\right)+\delta_{j}+e_{i j k}
$$

where $m$ is the average value of the difference over the range of densities* $D_{i}, s$ is the slope over this range, $\bar{D}$ is the average of the $D_{i}, \delta_{j}$ is a differential shift occurring on the $j$ th filling, and $e_{i j k}$ is the random error occurring for the $k$ th measurement of $\mathrm{D}_{i}$ in the jth filling. The $\delta_{j}$ can only be evaluated from the methane data since there were no repeated fillings of the other test liquids.

The scatter in the random components $e_{i j k}$ is expressed by their standard deviation. This will be called the within or within filling standard deviation. If the $\delta_{j}$ are also considered to be random, their standard deviation is called the between or between fillings standard deviation. All these parameters may also be functions of the liquid compositions. For a glossary of the statistical terms, see Appendix 1.

When an estimated standard deviation is given, the degrees of freedom (d.f.) are also given. Degrees of freedom is a measure of the amount of information available for estimating a standard deviation. The d.f. is usually the number of measurements less the number of other estimated parameters. For example, for methane there were 53 measurements. If $\mathrm{m}, \mathrm{s}$ and the four differential shifts $\delta_{j}$ are estimated, there would be 47 degrees of freedom remaining to estimate the within standard deviation.

The experimental data are fitted to the model given by equation (4) using the method of least squares. The test of this model is if it provides a statistically better fit than if some or all of the unknown parameters were to be taken as zero. The tests for the presence of the parameters are made at the $5 \%$ level of significance, i.e., there is a $5 \%$ chance that the test will say to include a parameter that is not needed to explain the data. At a smaller level of significance there is less chance of including an unnecessary parameter, but there would also be less chance of finding a useful parameter.

When estimates of $\mathrm{m}, \mathrm{s}$, and $\delta_{j}$ are given, they are usually given in terms of confidence intervals, e.g.,

$$
\hat{m} \pm t \cdot(s t d \cdot d e v \text {. of } m)
$$

where $\hat{\mathrm{m}}$ is the estimate for $\mathrm{m}$ and $t$ is a percentage point of the $t$ distribution [6] depending on degrees of freedom and the level of confidence desired. The least squares procedure used to fit the data to equation (4) supplies

* The true value of $\mathrm{D}_{i}$ is unknown; the DRS value is used instead. The range of the $\mathrm{D}_{i}$ is large compared to the random error of the DRS; so the error introduced by this should not be important. 
both estimates of $\mathrm{m}$ and its standard deviation. A 95\% confidence interval used in estimating the value of a parameter means that 95\% of the time when such a confidence interval is constructed it contains the true value of the parameter.

No total uncertainty has been derived here for any of the densimeters tested since some of the instruments were not provided with low-temperature calibrations. A total measurement of uncertainty would include limits of error associated with calibration procedures, the limits of random error (precision) and the limits on those systematic errors that result from changes in the conditions under which the densimeter operates. Each of the densimeters is compared to the DRS and the components of the error are presented; i.e., those associated with $\delta_{j}$ and $e_{i j k}$.

In the description of each of the following comparisons, a table is provided which gives a breakdown by composition of the statistical significance of the average value, $m$, the slope, $s$, and the largest $\delta_{j} \cdot A 95 \%$ confidence interval is given for each significant parameter. The table gives the within standard deviation (WSD) as well as the between standard deviation (BSD) for the $\delta_{j}$. It is not clear that the $\delta_{j}$ are random for any densimeter -- in some cases it is clear they are not -- so the between standard deviations should be viewed in this context.

4.1 Comparison of Haynes-Hiza and Density Reference System Density Determinations.

As discussed earlier, the Haynes-Hiza temperature-density relationship for liquid methane [3], which agrees within experimental uncertainty with the correlations of Goodwin [2], has been used to confirm the DRS density results. The percent deviations of the HH density from the corresponding DRS density determination for the five fillings are shown as a function of the chronological order of the data in figure 2. This replication of the methane data over a number of fillings provides a means of checking the reproducibility of a densimeter from one filling to the next. In this instance, the means of the five groups, $m+\delta j^{\prime}$ are not statistically different. Figure 3 shows the percent deviation as a function of density for the DRS. The figure shows what appears to be a second. degree effect. While it would not be surprising to find this kind of systematic difference between the two methods, the data does not support this at the 5\% level of significance. However, an offset is detectable at the 5\% level. See table 2. This offset is well within the systematic error of the DRS [1]. 
Table 2. Statistical summary for HH-DRS

Methane

Significant at 5\% level? 95\% confidence interval $\left(\mathrm{kg} / \mathrm{m}^{3}\right)$

m

S

Largest $\delta_{j}$

WSD $=0.065 \mathrm{~kg} / \mathrm{m}^{3}$

BSD = not significant

Here, as in all the following comparisons, a standard deviation, whether within or between, combines the imprecision of both methods of determining density.

\section{Summary}

The differences between the densities determined by these two methods do show a small systematic offset, but no filling-to-filling changes, and the estimate of their combined standard deviations is $0.065 \mathrm{~kg} / \mathrm{m}^{3}$. For the methane normal boiling point density of $423.63 \mathrm{~kg} / \mathrm{m}^{3}$, this standard deviation is equivalent to $0.016 \%$. 


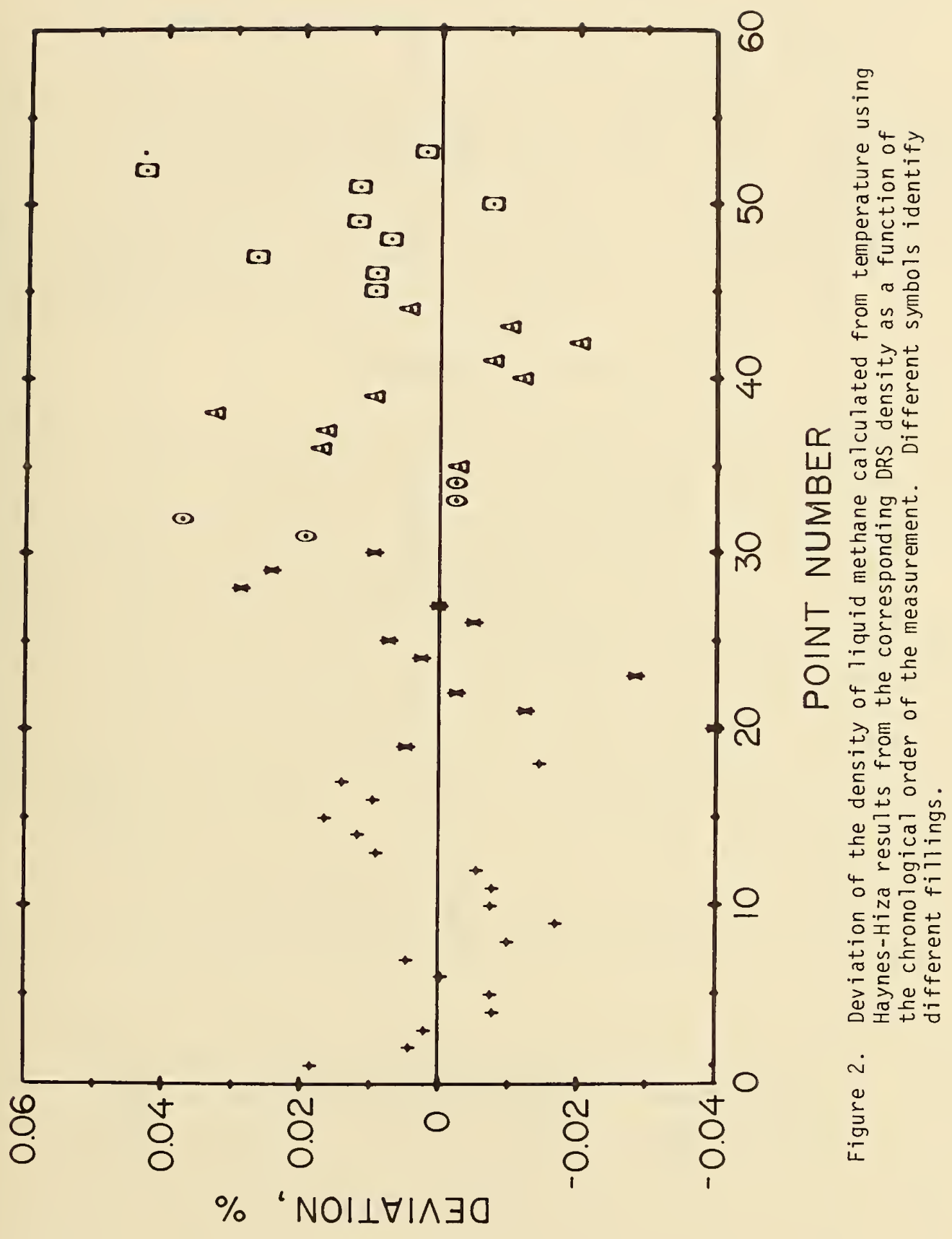




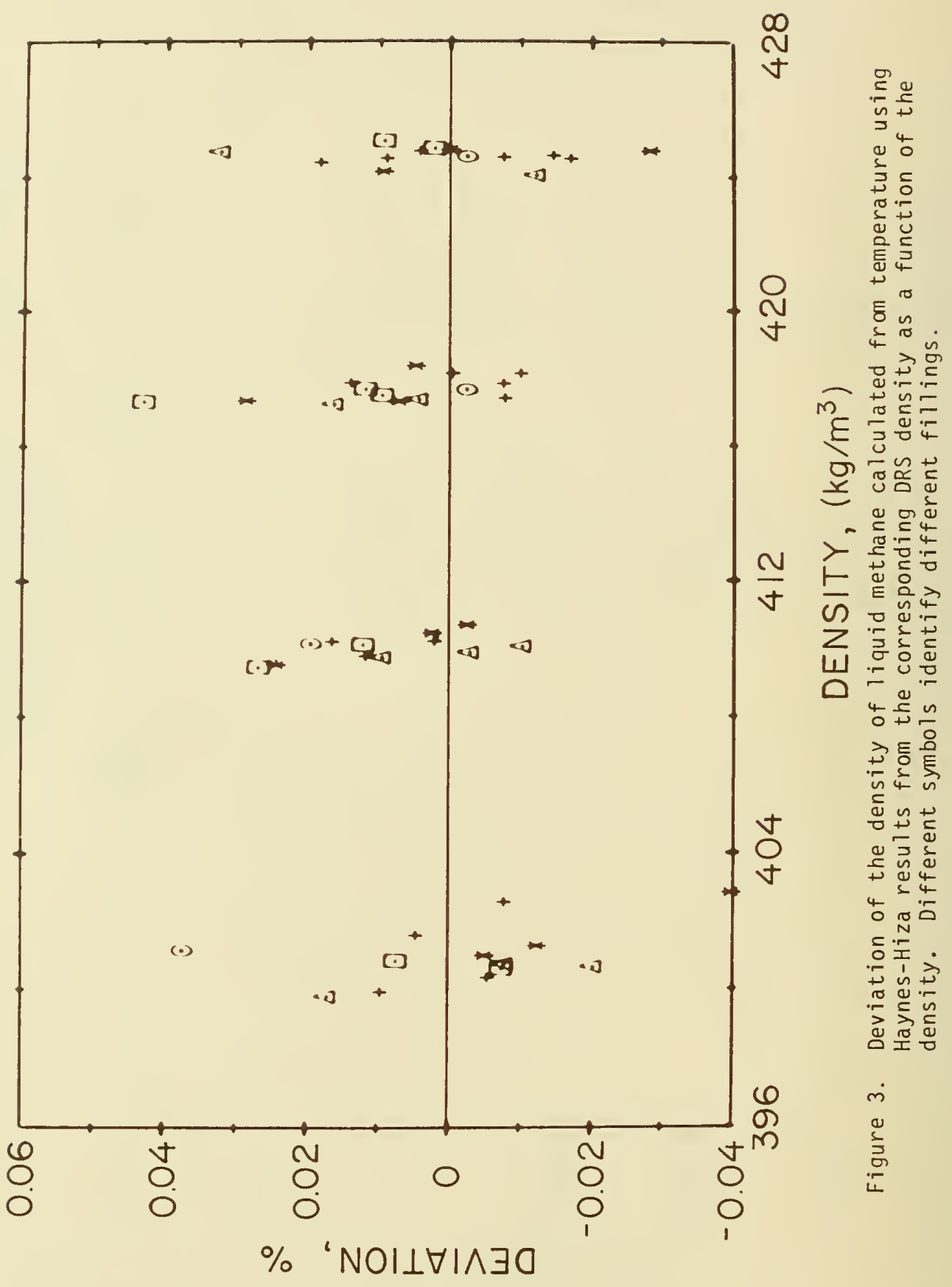


4.2 The Vibrating Cylinder Densimeter

The vibrating cylinder densimeter is shown schematically in figure 4. The vibrating cylinder secondary electronic output meter can be adjusted to indicate a minimum density as the zero indication and a maximum density as the full scale reading. It was found that initial settings recommended by the supplier produced an offset of several percent in density.

Since the calibration supplied with this instrument was not suitable, the instrument was recalibrated using the experimental data. The resonant frequency of the instrument was measured directly using a frequency counter with an $0.1 \mathrm{~Hz}$ resolution. Some of the resonant frequency and the corresponding DRS density data were used to determine the constants of equation (1) by means of a least squares fit. The result is,

$$
\rho=-203.3672+5719.149 / f^{2}
$$

where $f$ is the frequency in $\mathrm{kHz}$ and $\rho$ is in $\mathrm{kg} / \mathrm{m}^{3}$. This calibration equation was fit to all the data except that of the last methane run. The calibration was done for the purpose of comparing the instrument to the DRS. The analysis of the data below indicates that a better fit might be obtained if a linear term in $1 / f$ or temperature were included in equation (5).

The percent differences for the five methane runs are given in figure 5 in the order taken. There are some obvious differences in the operation of the meter from one filling to the next--the upward shift during the second day of the first run and the shift down on the last run--that are statistically significant when based on the estimated within filling standard deviation of $0.20 \mathrm{~kg} / \mathrm{m}^{3}(47 \mathrm{~d} . \mathrm{f}$.$) . The data for the first filling was made$ over two days, and there is a shift in the data between the two days, thus inflating the standard deviation for that filling. If one eliminates the data for the first filling, the estimated within standard deviation is 0.092 $\mathrm{kg} / \mathrm{m}^{3}-(27$ d.f. $)$.

Occasionally a measurement by this densimeter indicated a considerably smaller density than the corresponding DRS measurement. At the same time the variation of the frequency reading, normally $\pm 0.1 \mathrm{~Hz}$, increased to about \pm 1 $\mathrm{Hz}$. This increased "noise" in the frequency reading was probably due to the presence of bubbles on the vibrating element and these data were excluded. These noisy measurements occurred after the liquid sample had been rapidly cooled, thus there could be some boiling near the vibrating element. No controlled tests were done to see whether any liquid level effects exist. A too low liquid level could degrade both the accuracy and precision of a density measurement.

Both the methane and LNG mixtures were used to fit equation (5). The estimates of $\mathrm{m}$ for the various mixtures, given in Table 3 , indicate there 
could be a shift for the higher nitrogen content; but comparable shifts did occur for the pure methane data (figure 5).

Equation (5) takes density, but not temperature, directly into account. Because both methane and LNG mixtures were used, temperature and density are not directly related; the temperature ranges for the mixtures are about the same in each case, but the density ranges are not. As can be seen in figure 6 for methane, the percentage differences show evidence of what could be a temperature dependence, since the measurements are at saturation. Four of the values of $s$ for the five fluids are significantly different from zero at the 5\% level (see table 3), and there is a consistency in these estimates with those for LNG being larger than those for methane.

The LNG data, figures 7 and 8 , showed more variability than the methane data. The combined standard deviation for the two LNG runs is $0.51 \mathrm{~kg} / \mathrm{m}^{3}(20$ d.f.), which is significantly different from the estimated standard deviation of $0.20 \mathrm{~kg} / \mathrm{m}^{3}(47 \mathrm{~d} . \mathrm{f}$.$) for pure methane.$

The shifts seen in figure 5 are significant, about $0.1 \%$ between the first and second days of the first filling, and $0.05 \%$ between the last two methane fillings. It cannot be said whether these shifts are random in nature or are due to some overlooked systematic effect.

\section{Summary}

The calibration using eq. (1) removed most of the systematic offset for this densimeter, but some density dependence is indicated. Whether the shifts seen in the methane data are random or otherwise cannot be determined at this time. The estimated within standard deviation increases significantly for LNG. 


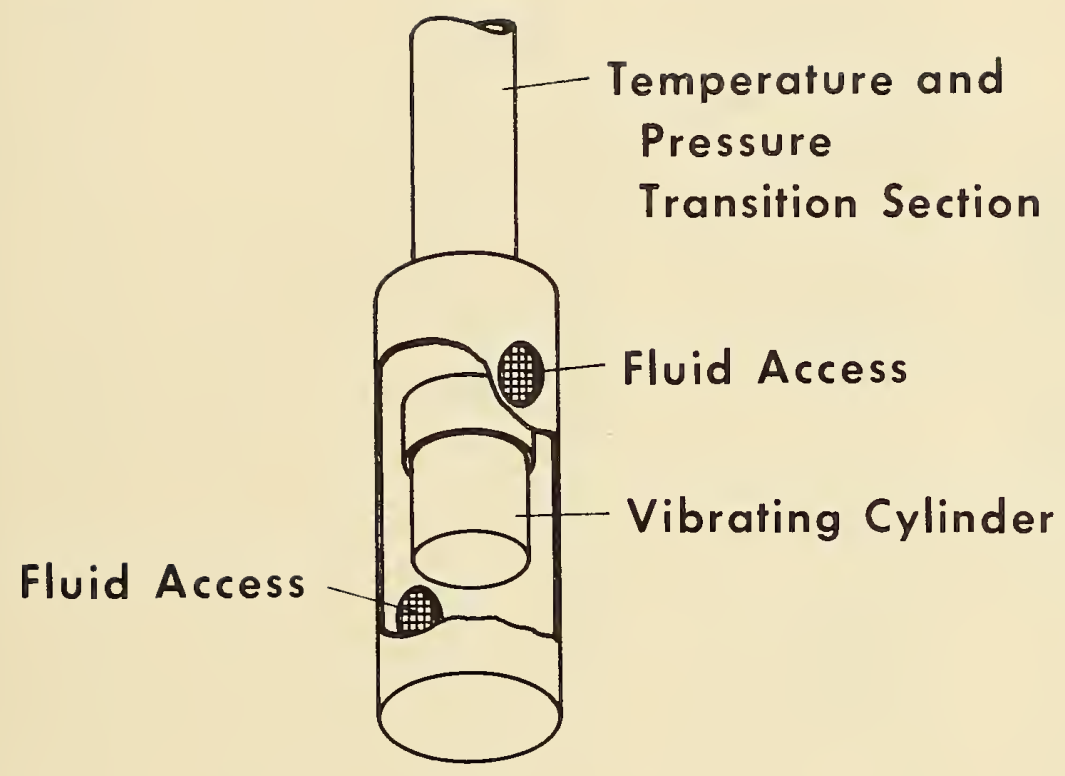

\section{VIBRATING CYLINDER \\ DENSIMETER}

Figure 4. 


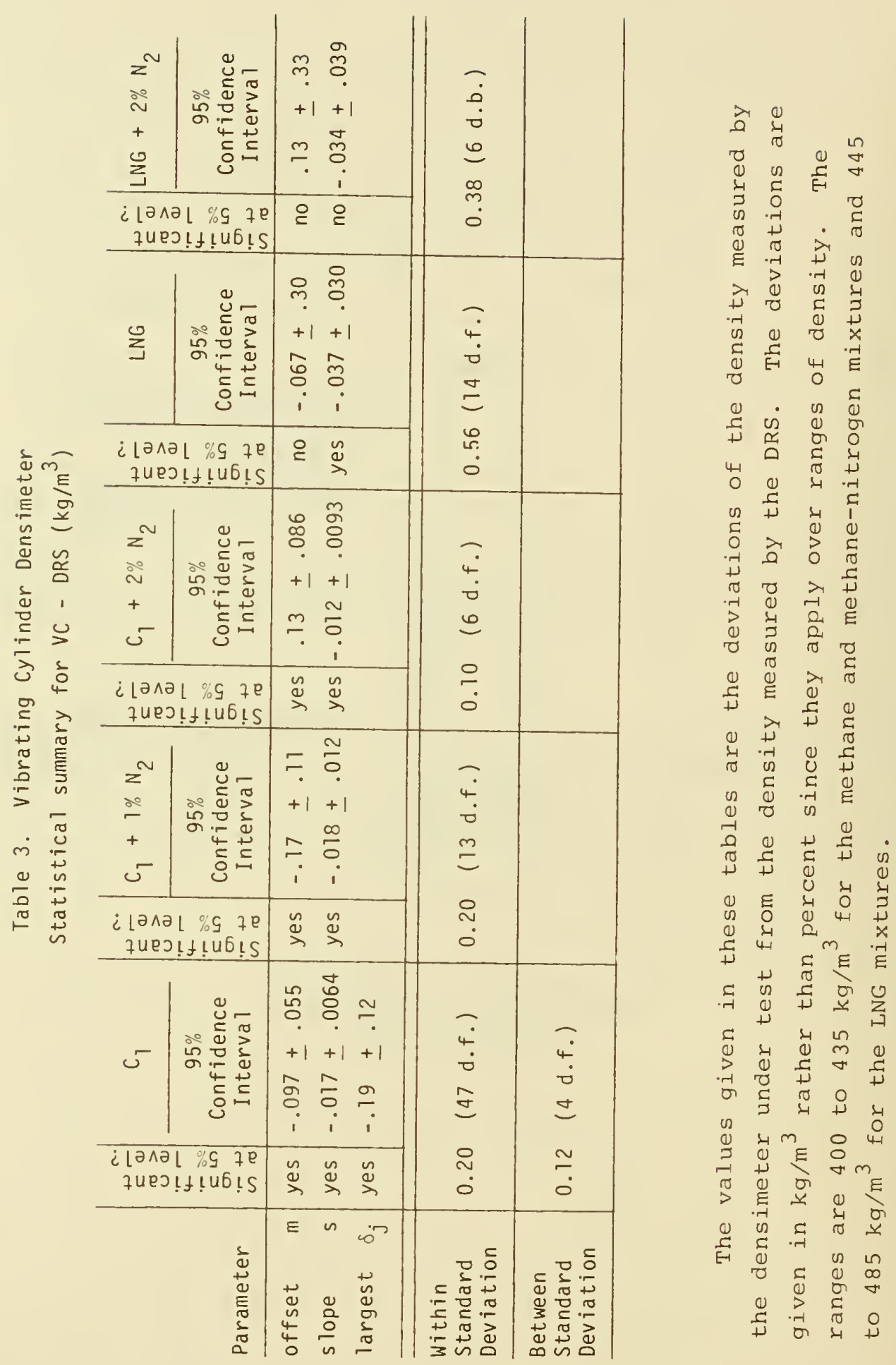




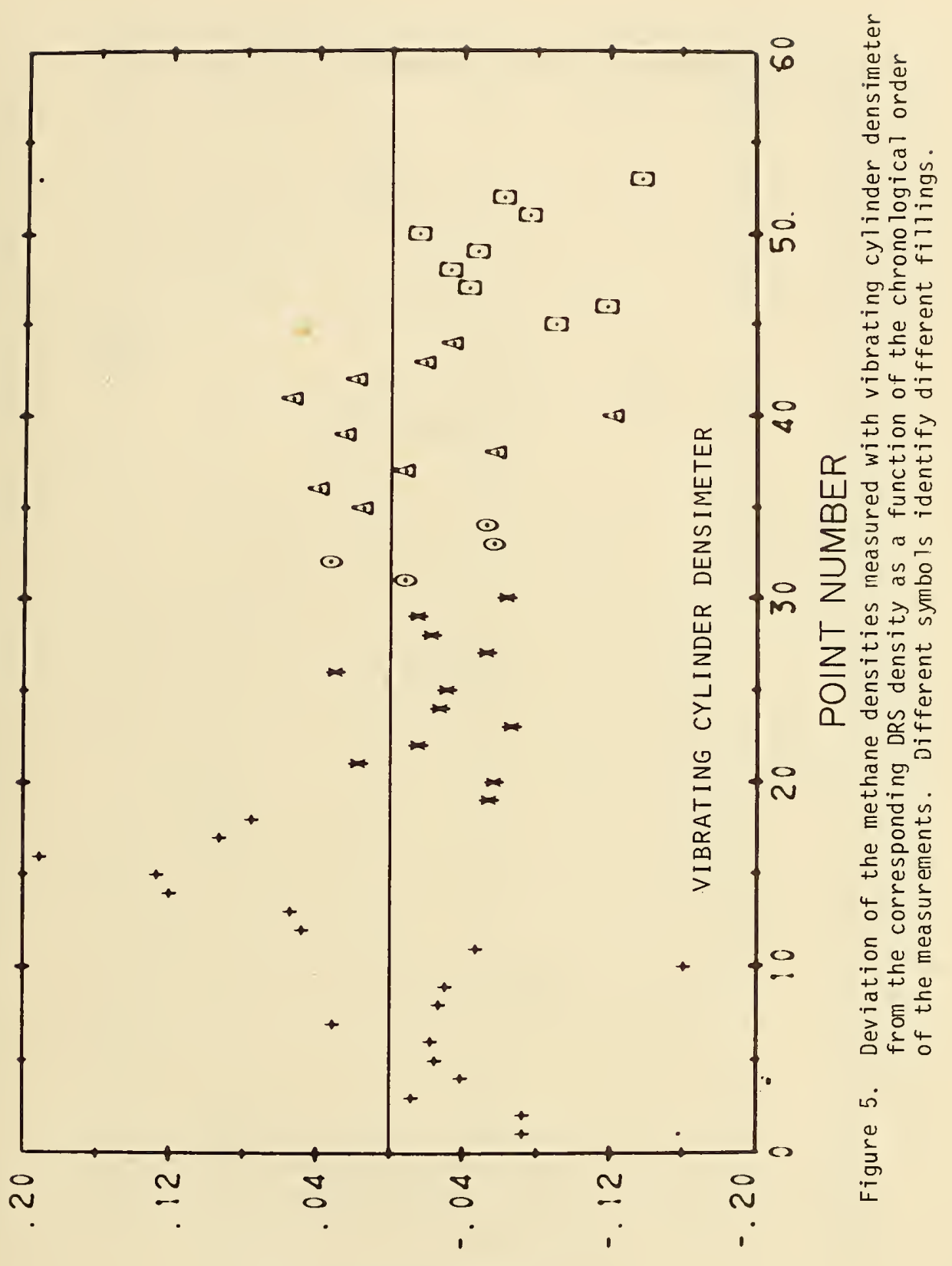

(\%) $N O I \perp \forall \mid \wedge \exists O$ 


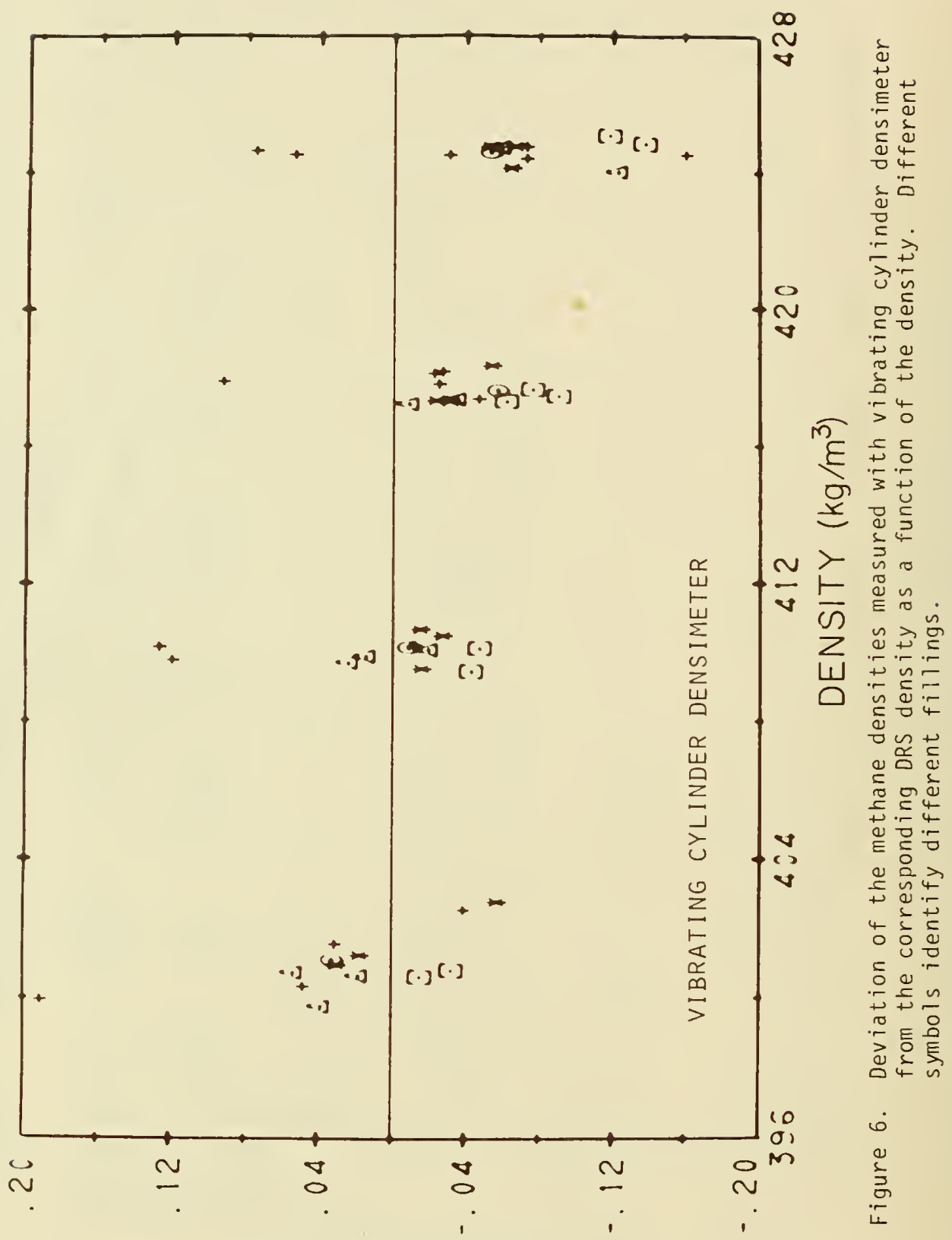

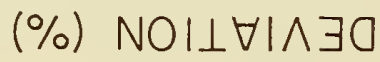




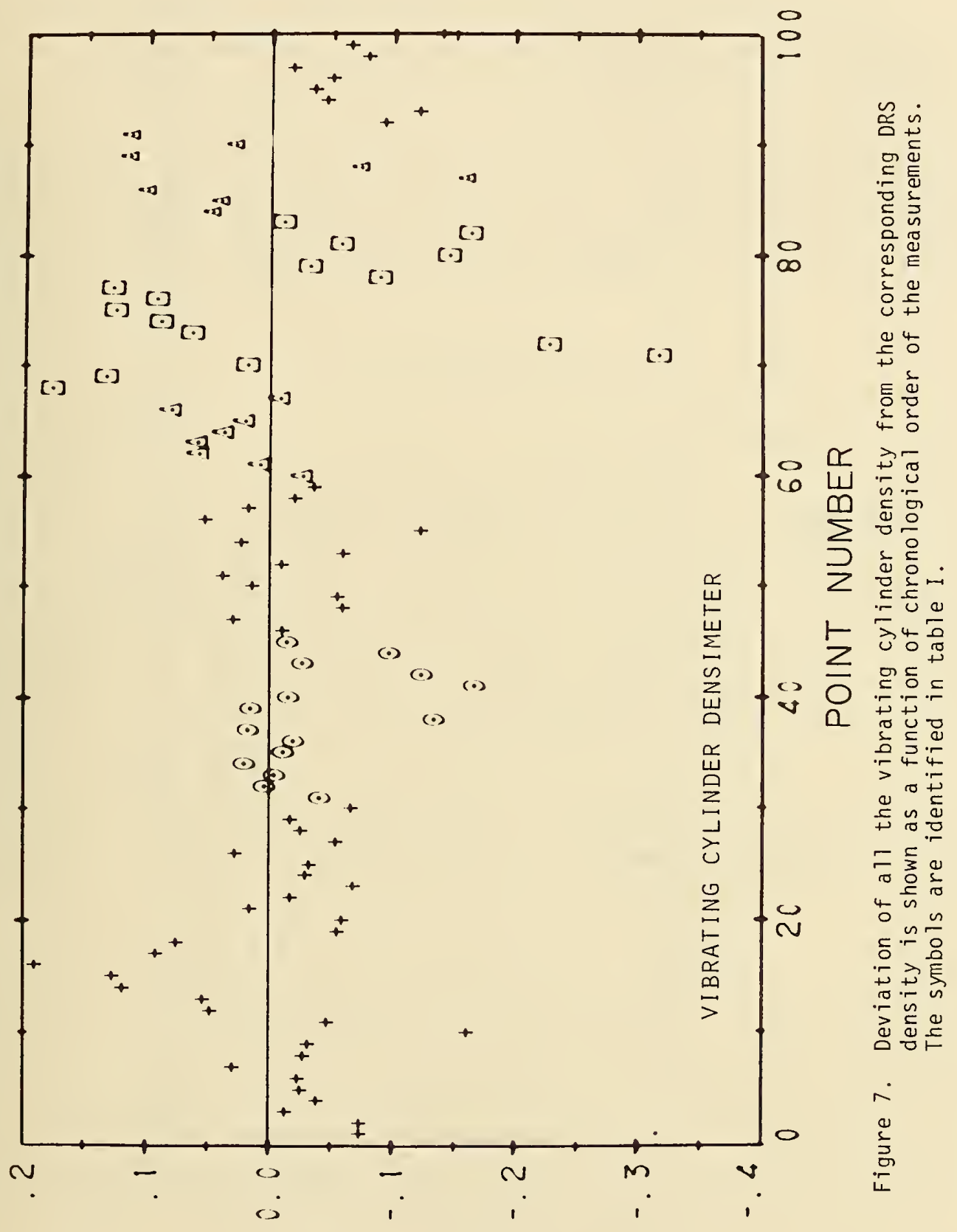

(\%) $N O|\perp \forall| \wedge \exists O$ 


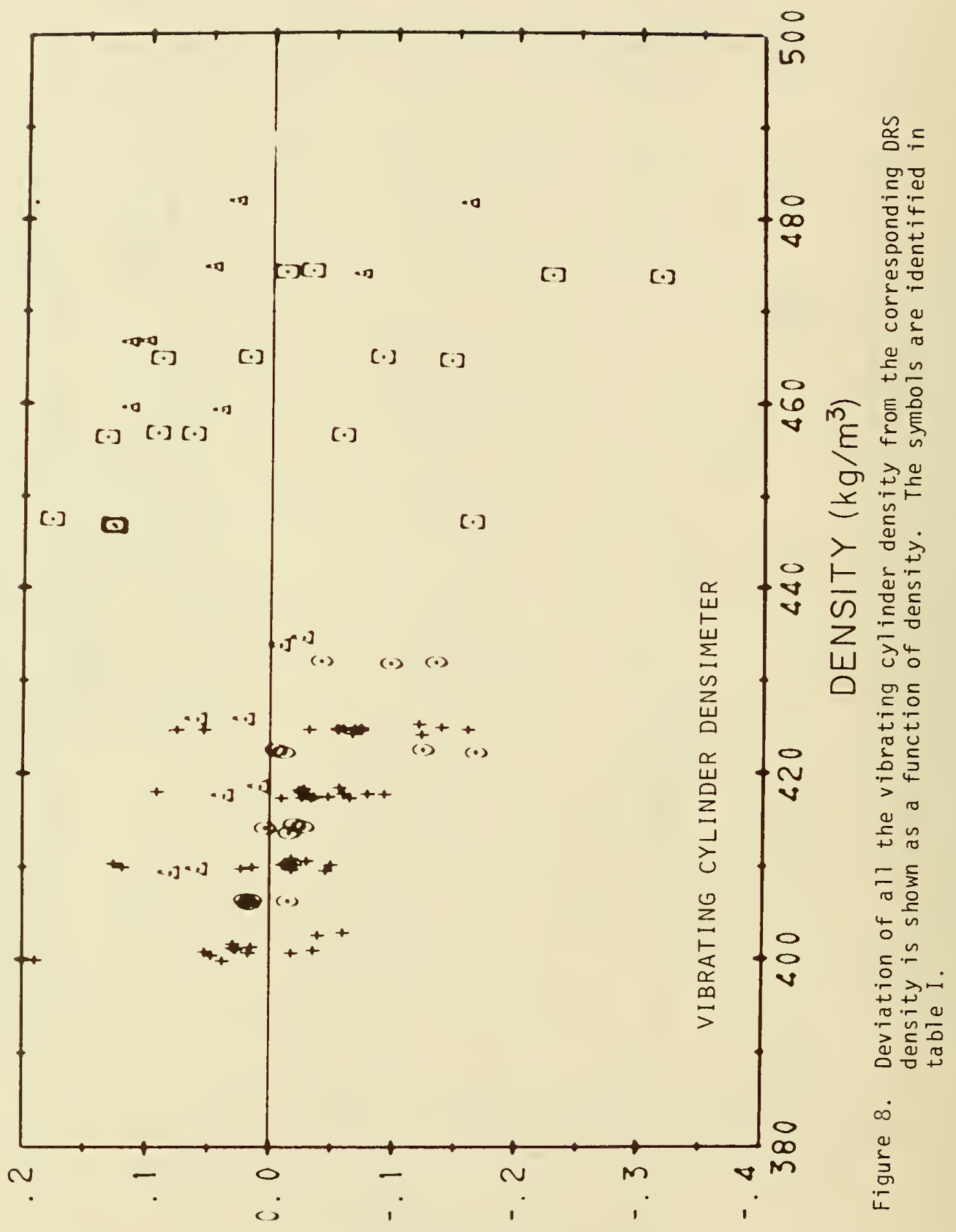

(\%) NOI $\forall \mid \wedge \exists O$ 


\subsection{Vibrating Plate Densimeter}

The vibrating plate densimeter is shown schematically in fig. 9. The calibration supplied with this instrument was for more dense fluids at room temperature. Since the direct density reading of the instrument was $1.6 \%$ high, the resonant frequency was measured directly using a frequency counter with a $0.1 \mathrm{~Hz}$ resolution. A calibration equation for the vibrating plate densimeter was then determined by a least squares fit of equation (1) to the resonant frequency of the densimeter and the corresponding DRS density. The fit was made to the pure methane and the LNG mixture data only. No mixtures containing $\mathrm{N}_{2}$ were included in the calibration for the reasons discussed below. The calibration equation derived is:

$$
\rho=-550.1099+5430.736 / \mathrm{f}^{2}
$$

where $\mathrm{f}$ is in $\mathrm{kHz}$ and $\rho$ is in $\mathrm{kg} / \mathrm{m}^{3}$. This equation was used to compare the density measurements of this instrument with the DRS.

Figure 10 shows the percent differences for the five methane runs in the chronological order taken. Figure 11 shows the same data as a function of density. This instrument occasionally read a significantly lower density than the DRS while the random variation of frequency readings increased significantly. The increase in noise was attributed to bubble formations on the vane as a result of rapid cooling of the test liquid and the data are not shown in the figures.

There is some shifting of the mean level within and between fillings. If the $\delta_{j}$ are taken to be random, the estimate of their standard deviation is $0.20 \mathrm{~kg} / \mathrm{m}^{3}$ ( $\left.4 \mathrm{~d} . \mathrm{f}.\right)$. The data for the fifth filling showed the largest shift. There is no obvious explanation for these shifts in terms of systematic effects.

Figure 12 shows the percent deviation for all liquids in chronological order. The within run standard deviations among the liquids are not judged to be significantly different. See table 4 for the within standard deviations for each liquid. The estimated within standard deviation for the differences using both methane and mixture data is $0.16 \mathrm{~kg} / \mathrm{m}^{3}$ ( $88 \mathrm{~d} . \mathrm{f}$. ). The mean values for all liquids containing nitrogen were found to be significantly different from zero in the positive direction (see table 4). The LNG plus nitrogen offset is statistically smaller than those for the methane plus nitrogen mixtures. This could have been influenced by whatever caused the large downward shift in the last methane data. In regard to this, it should be noted that no filling-to-filling effects were taken in to account in forming the confidence intervals for $\mathrm{m}$ in table 4. 
Figure 13 shows the percent deviation for all the sample fluids versus density. Only the differences for the LNG with no nitrogen data shows a statistically significant trend with density and/or temperature. There is no obvious explanation for this, and since it does not occur for the LNG data without nitrogen, it may be anomalous. The estimated within standard deviation does not seem to change with composition.

\section{Summary}

The calibration of this densimeter is nitrogen dependent, but there does not appear to be any strong evidence of a temperature or density dependence that has not been removed by the calibration. There are shifts in the mean level from filling to filling, the largest of which occurs on the fifth filling. The estimated within standard deviation does not show a statistically significant change with composition. 


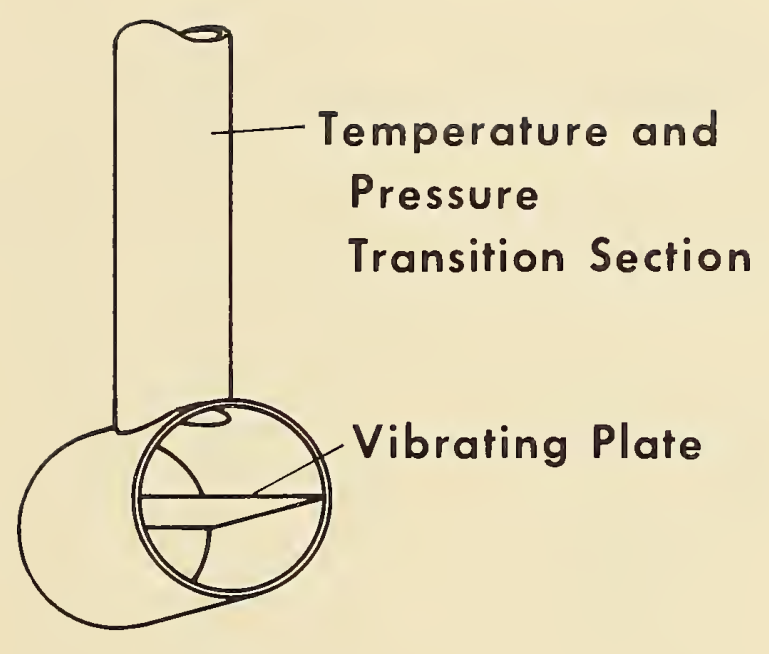

\section{VIBRATING PLATE DENSIMETER}

Figure 9. 


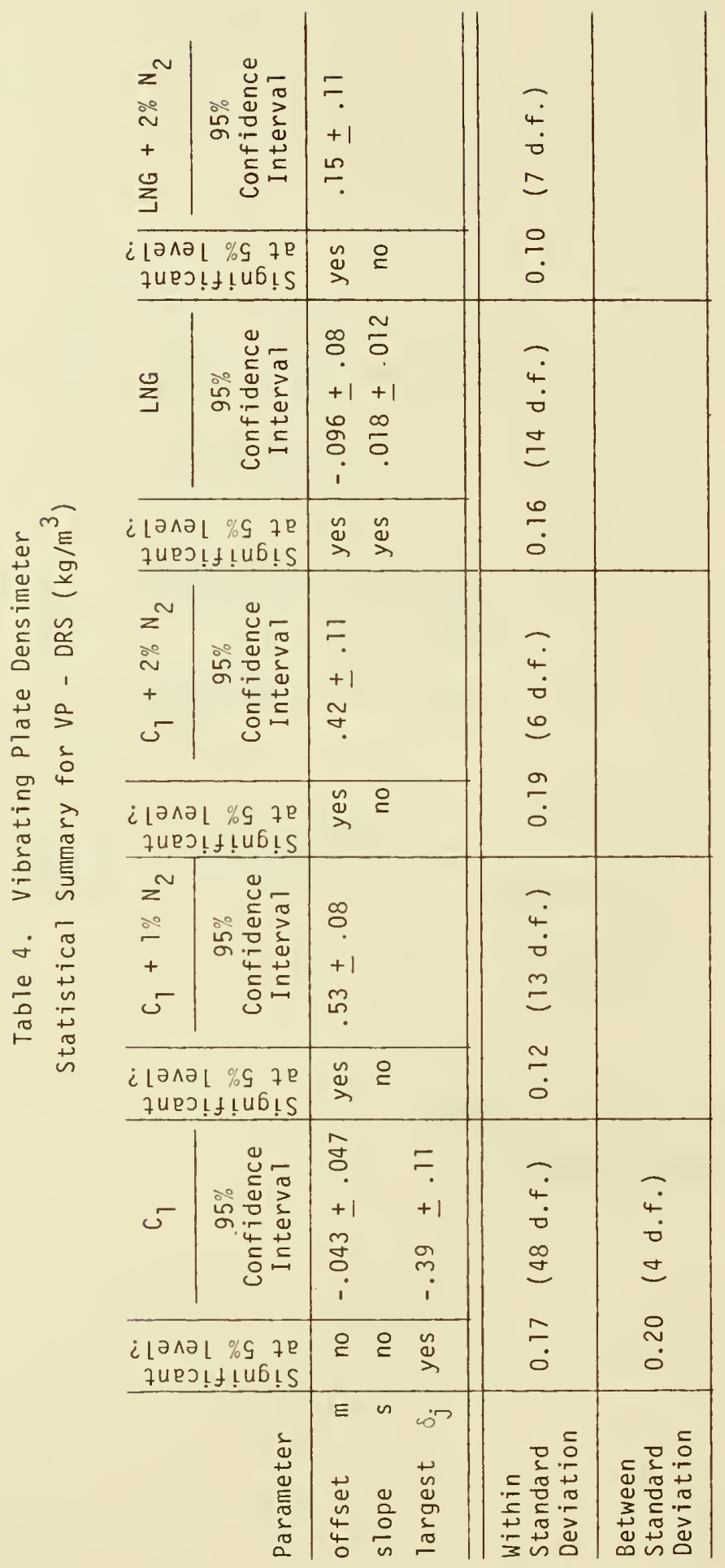

ลे

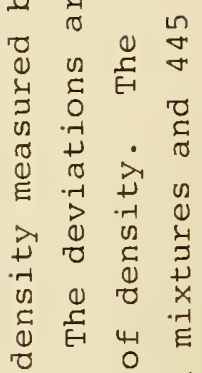

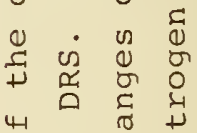

4

(2)

¿ी

$+$

\%

(1) थू ह

丳

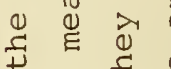

(1) \

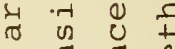

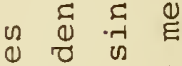

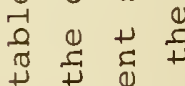

- E U ک

थ 0 ए

मु

द पू पू के

¿

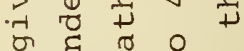

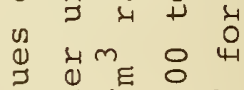

ते है ने

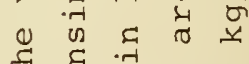

E

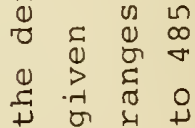




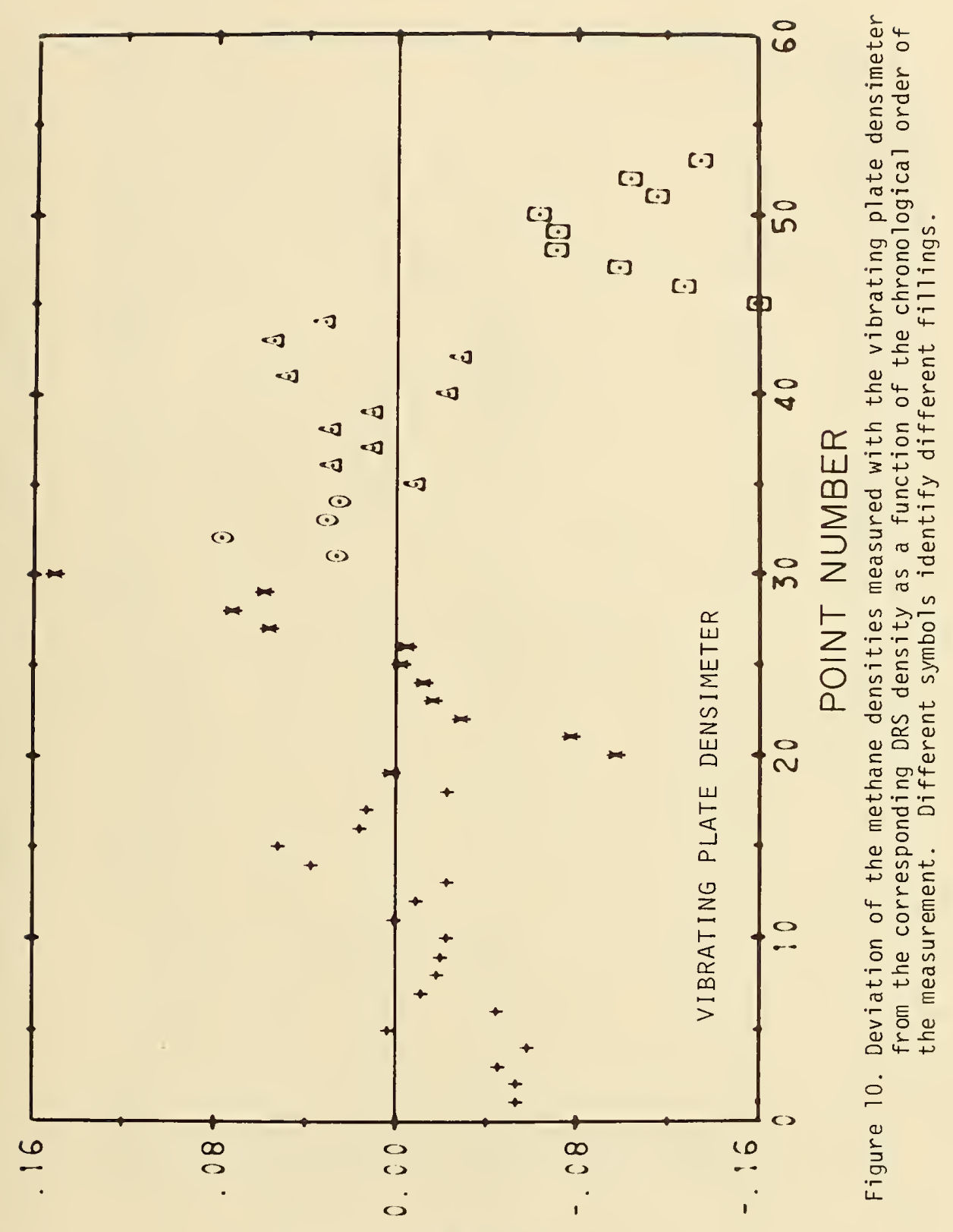

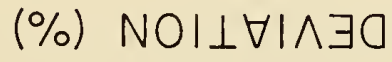




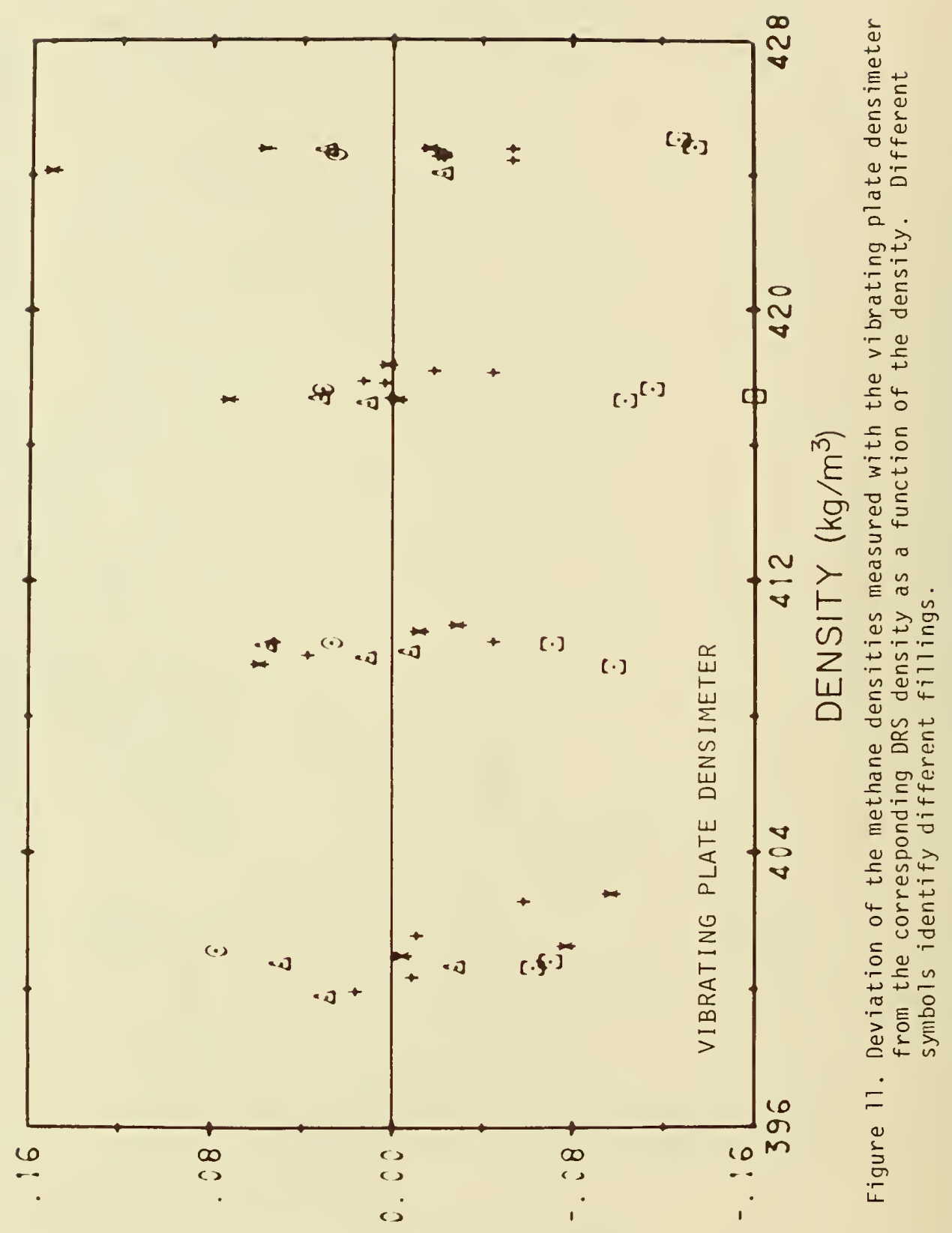

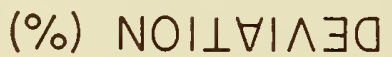




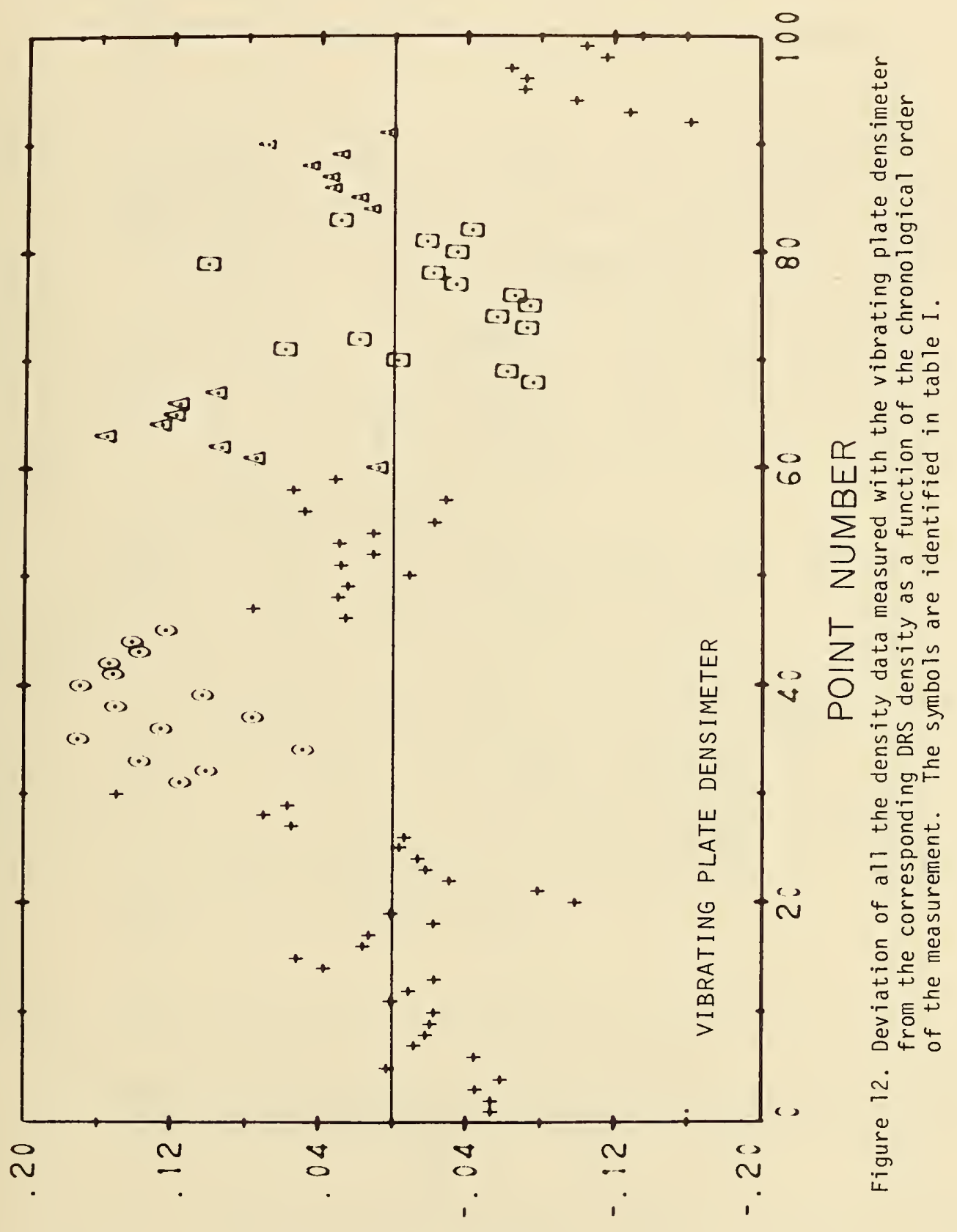

(\%) $N O I \perp \forall \mid \wedge \exists O$ 


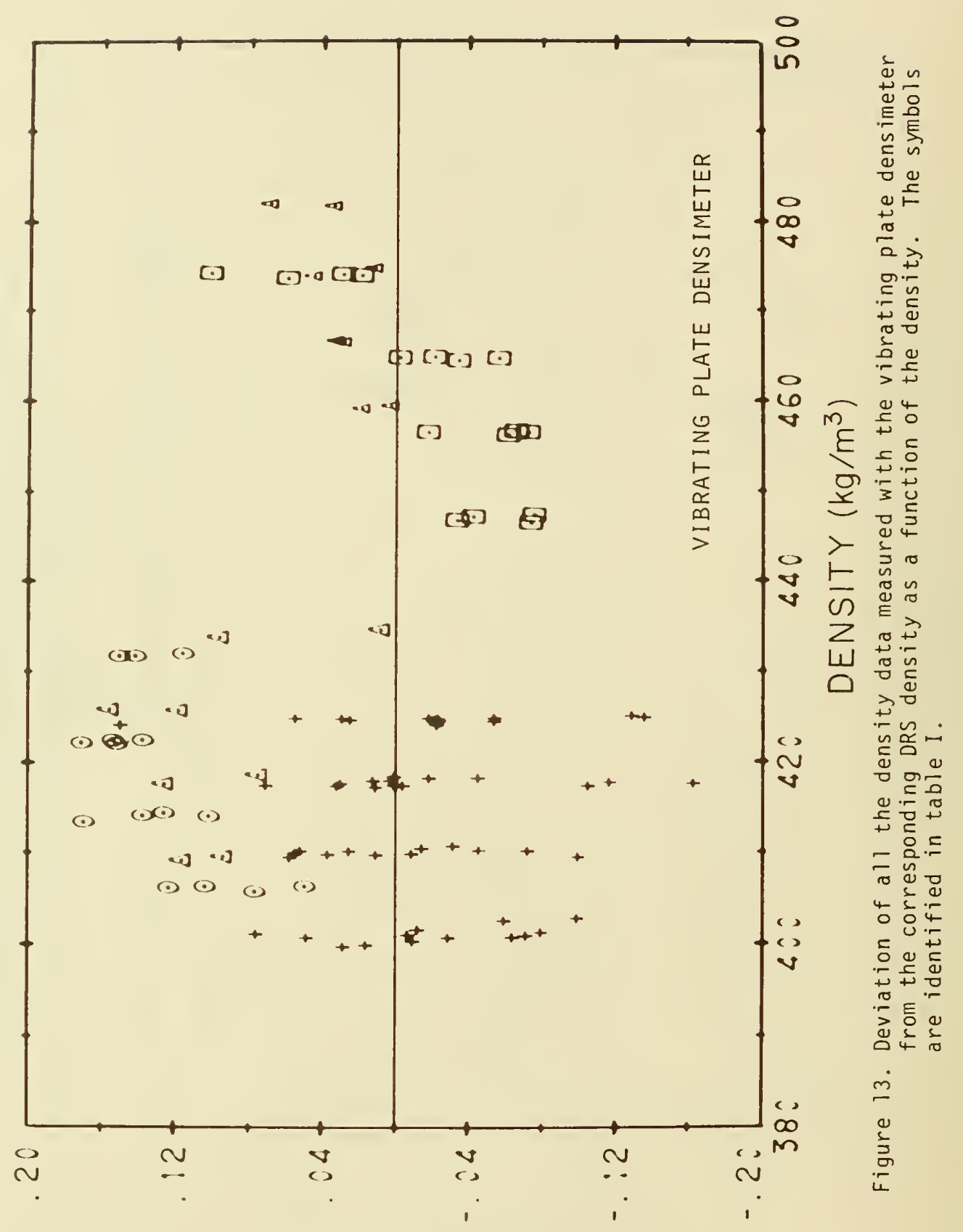

(\%) $N O I \perp \forall \mid \wedge \exists O$ 
4.4 Capacitance or Dielectric Type Densimeter

This capacitance system uses a relation linear in dielectric constant, $\varepsilon$, and temperature, $T$, to determine $\rho$,

$$
\rho=A+B(\varepsilon-1)+C T
$$

the values of $A, B$, and $C$ having been selected from the designer's studies of properties of LNG-type mixtures of methane, ethane, propane and normal butane. The dielectric cell densimeter is shown schematically in figure 14.

After the "first methane sample density measurements, this densimeter was readjusted. The data for this first run was then recalculated in accordance with the adjustment. The plot of the percent deviations for all the methane data versus order -- figure 15 -- shows significant shifting of the mean level from one filling to the next. Figure 16 gives the percent deviations of the methane data versus density. The apparent slope is exaggerated in this case by using percent, but even for the density differences the slope is significant.

Figure 17 displays the percent difference versus order for all liquids and figure 18 shows the percent difference versus density. The within standard deviation for various liquids does not differ significantly. The estimated within standard deviation based on all data is $0.078 \mathrm{~kg} / \mathrm{m}^{3}(86$ d.f.). It will be roted--see table 5--that the average difference changes with composition. The 95\% confidence intervals given in table 5 for the average differences are based on the between standard deviation, $0.32 \mathrm{~kg} / \mathrm{m}^{3}$, and this assumes the $\delta_{j}$ to be random. This assumption may not be supported by future testing. The 95\% confidence intervals for $s$ in table 5 indicate that slope also changes with composition.

\section{$\underline{\text { Summary }}$}

This densimeter was factory calibrated; and reads high for the liquids without nitrogen, and low for those containing nitrogen. Of lesser practical significance is a dependency on temperature or density. The shifts, $\delta_{j}$, are indeed significant when compared to the estimated within standard deviation.

Calculations by Giarratano and Collier [7] have shown that the density of an LNG mixture can be calculated from the dielectric constant and temperature using eq. (7) with some error. The size of this error varies with composition. The errors for LNG mixtures containing no nitrogen but ranging from pure methane to an LNG mixture similar to that studied here are as much as $0.4 \%$. The systematic offsets for the methane and LNG measurements in this evaluation show a difference of $0.5 \%$, in good agreement with their work. If nitrogen is included in the mixtures, the error range in the 
density determined from the dielectric constant and temperature becomes much larger. If the nitrogen concentration range is from 0 to $1.4 \%$, the error could be as much as $1.8 \%$. In this experiment, the methane plus nitrogen mixtures are nominally 0,1 and $2 \%$ nitrogen. From the offsets (figure 17), it is estimated by interpolation that for a nitrogen concentration range of 0 to $1.4 \%$ the error could be as large as $1.9 \%$, again in good agreement with Giarratano and Collier [7]. To realize a density measurement with a dielectric cell with an accuracy approaching the precision of such a cell requires that the composition, especially the amount of nitrogen, of the fluid in question be known. 


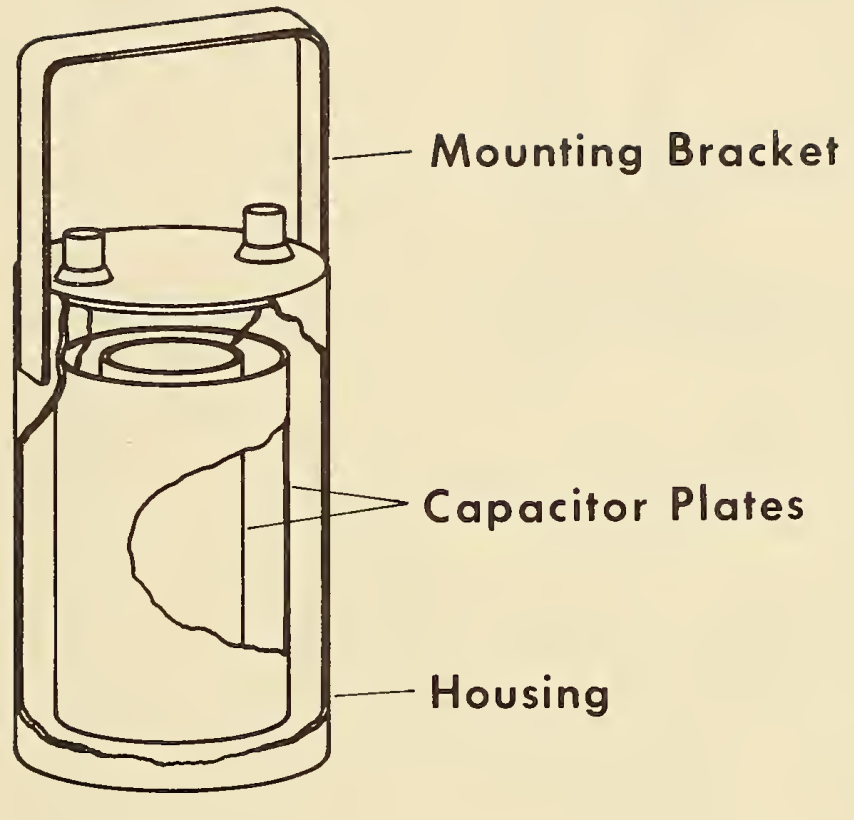

DIELECTRIC CELL DENSIMETER

Figure 14. 


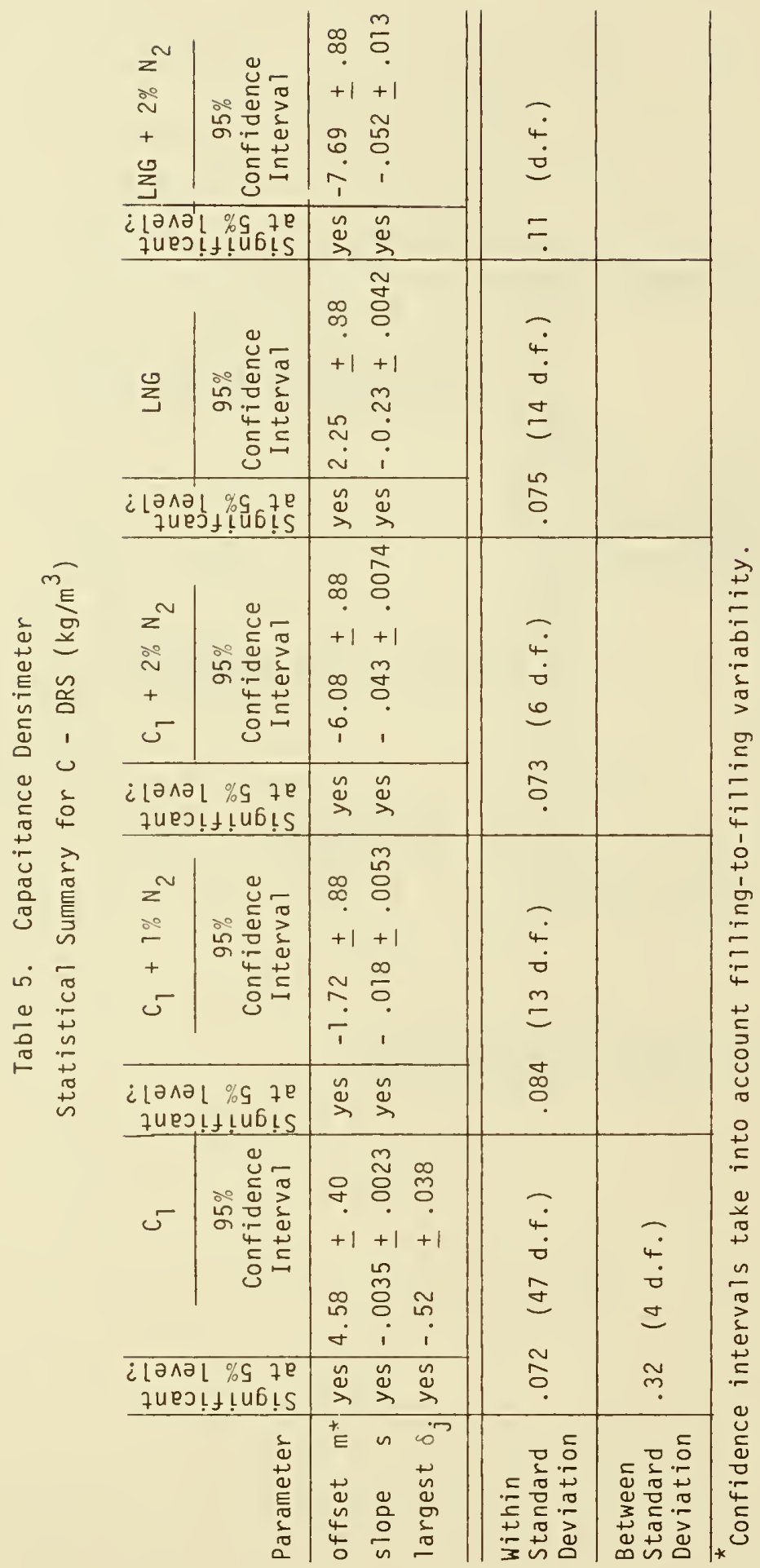

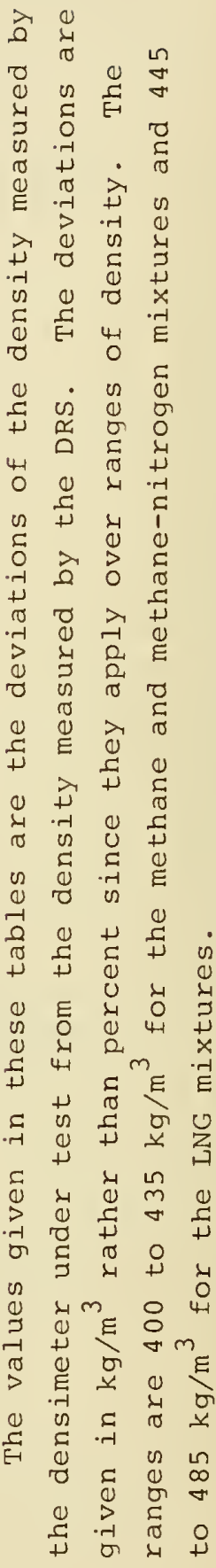




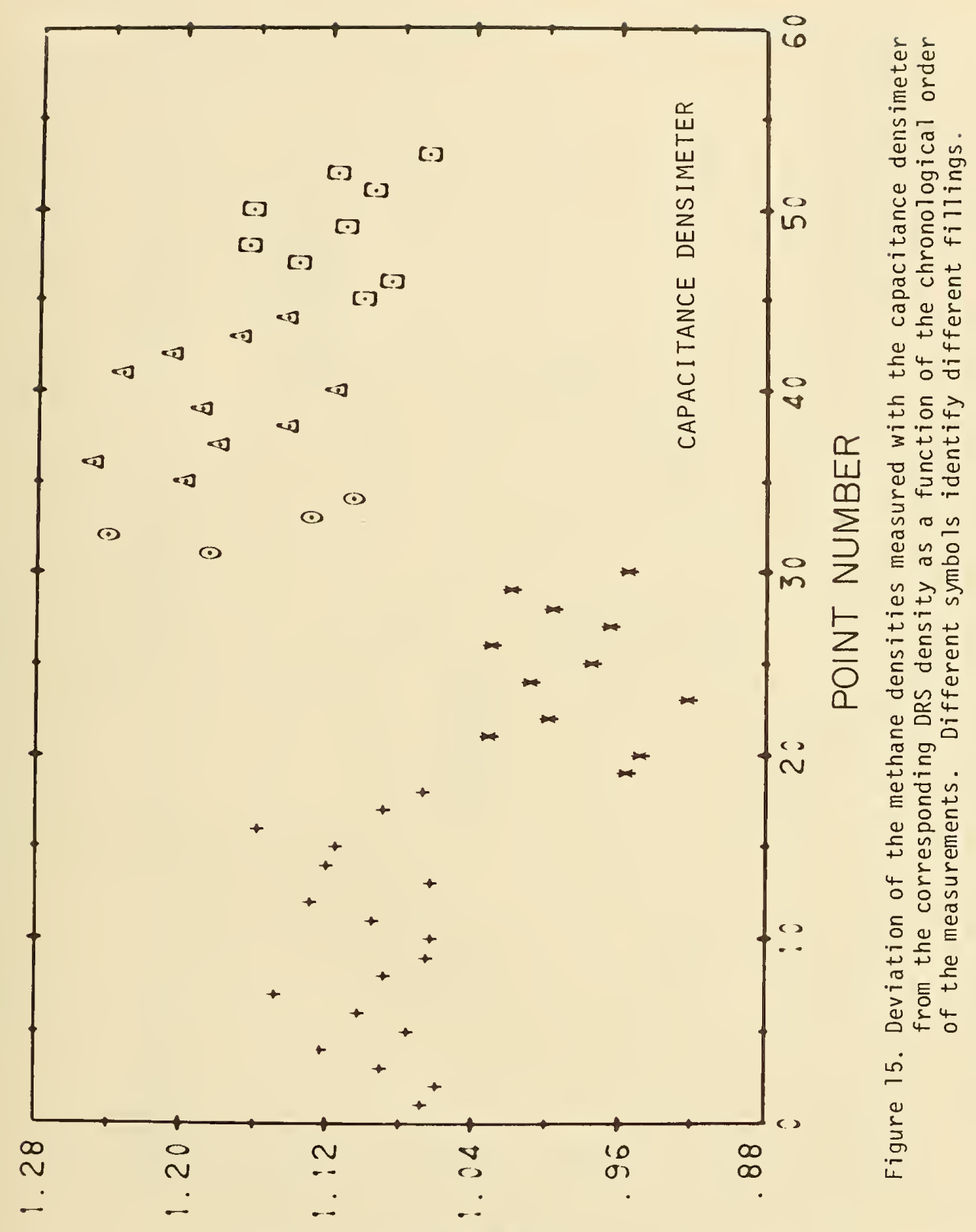

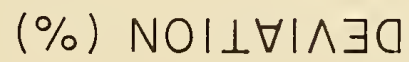




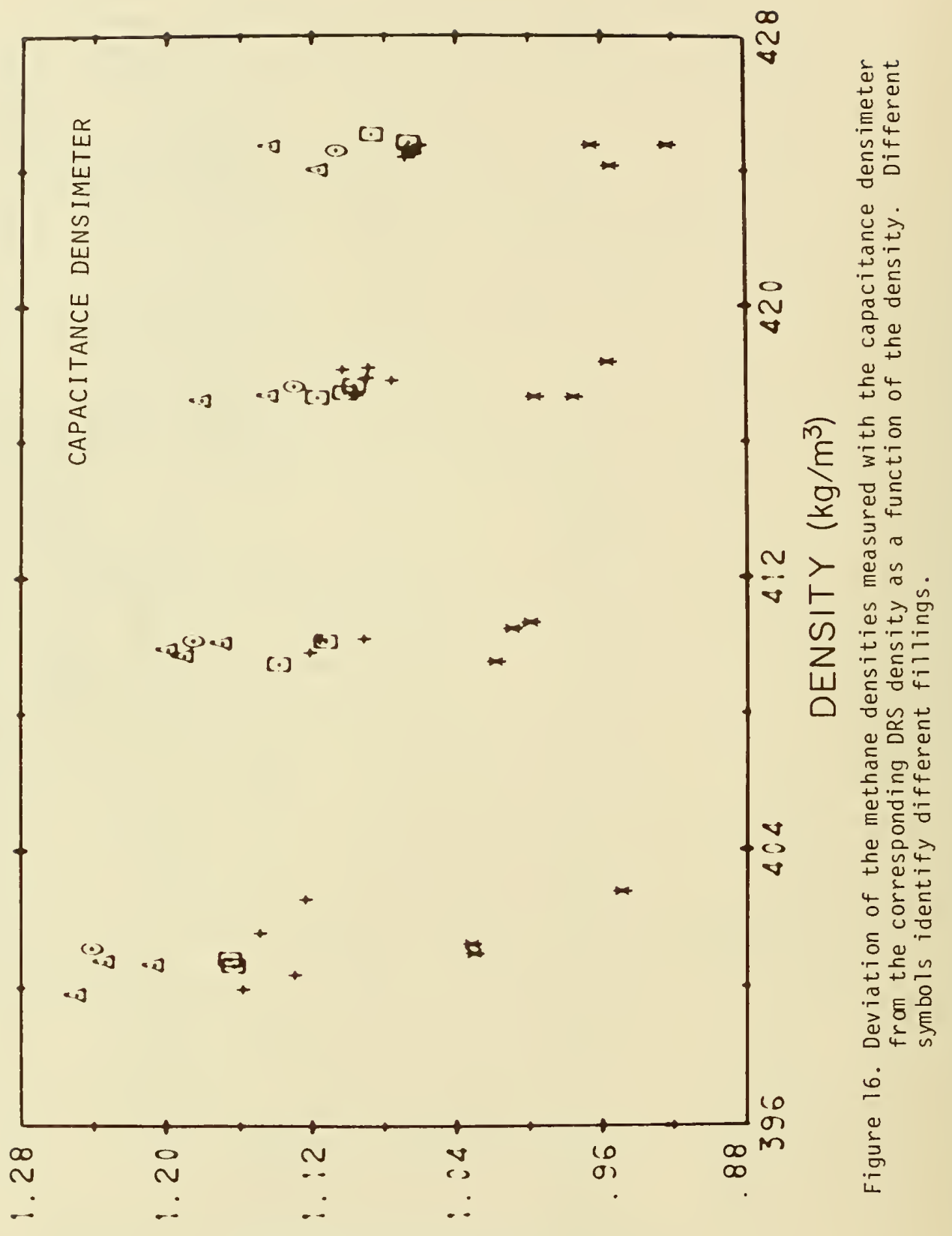

(\%) $N O I \perp \forall \mid \wedge \exists O$ 


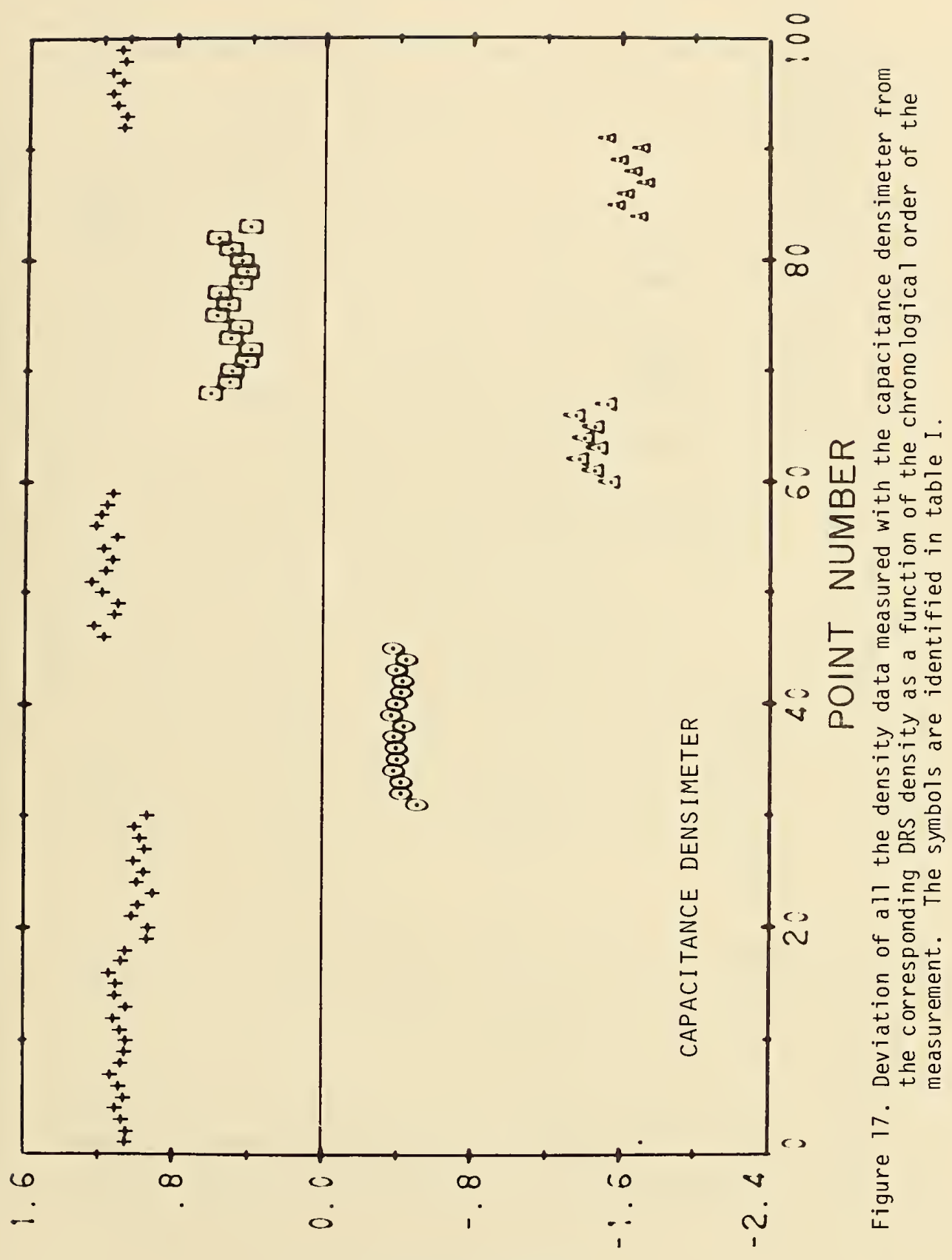

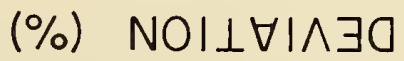




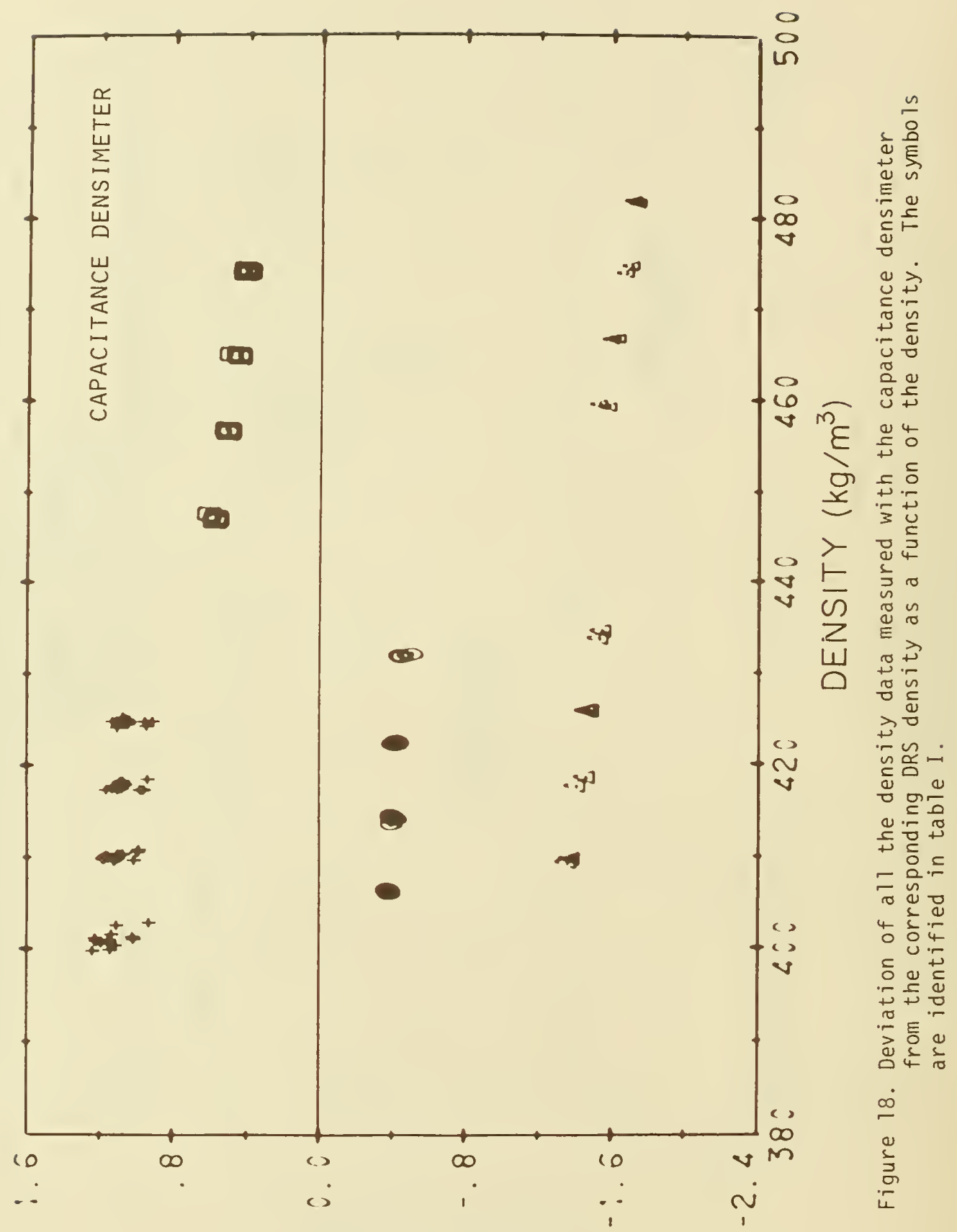

(\%) NOI $\triangle \forall \mid \wedge \exists O$ 


\subsection{The Displacement Densimeter}

The displacement or Archimedes densimeter is shown schematically in figure 19. This instrument consists of a float that is weighed by an electronic balance.

Figure 20 shows the percent deviation for the methane data versus order while figure 21 shows the same data as a function of density. This instrument was supplied with a factory calibration that agreed with the DRS to within $0.15 \%$ as shown in figure 22 .

The shift observed for the mean level on the second filling is significant. The mean levels for fillings 1,3 , and 4 (see table I) are not distinguishable on a statistical basis. A $95 \%$ confidence interval for the mean level based on these three fillings is $-0.17 \pm 0.025 \mathrm{~kg} / \mathrm{m}^{3}$. A 95\% confidence interval for the average value for filling 2 is $-0.53 \pm 0.040 \mathrm{~kg} / \mathrm{m}^{3}--$ a downshift of $0.36 \mathrm{~kg} / \mathrm{m}^{3}$. There is no obvious explanation for this shift. The calibration was adjusted for the last filling to bring the densimeter into agreement with the DRS. The mean of the differences on this last filling is $+.038 \pm .046 \mathrm{~kg} / \mathrm{m}^{3}$ which is not distinguishable from zero at the 5\% significance level. The percent difference for all liquids versus order are shown in figure 22 and versus density in 23. There is an apparent shift (see figure 22 and table 6) in the average of the differences when nitrogen is present in the methane, but this is not observed for the LNG mixture. It is not possible to determine from the data whether this small shift $10.025 \%$ maximum) is due to the DRS or this densimeter. There are no significant indications that this meter is temperature, density or composition dependent. The within standard deviation for all liquids is $0.07 \mathrm{~kg} / \mathrm{m}^{3}$ (9l d.f.).

\section{Summary}

The comparison in this case is between two Archimedes type densimeters, and it was not expected that composition would be a factor. The means for methane runs 1, 3, and 4 and the two LNG runs support this expectation. However, the addition of nitrogen to the methane in both cases produced detectable upward shifts in the means, though these may as well be due to the DRS. The small within standard deviation of $0.07 \mathrm{~kg} / \mathrm{m}^{3}$ (9l d.f.) make such shifts easy to detect. There was one notable and unexplained shift in the mean level of the differences -- from -.18 to $-.53 \mathrm{~kg} / \mathrm{m}^{3}$-- between the first and second fillings of the sample holder. The calibration adjustment made before the last filling resulted in an offset that was statistically indistinguisbable from zero. Temperature density or composition dependence does not seem to be a problem. The instrument calibration is such that the density measurements agree with the DRS to within the stated accuracy of the instrument. 


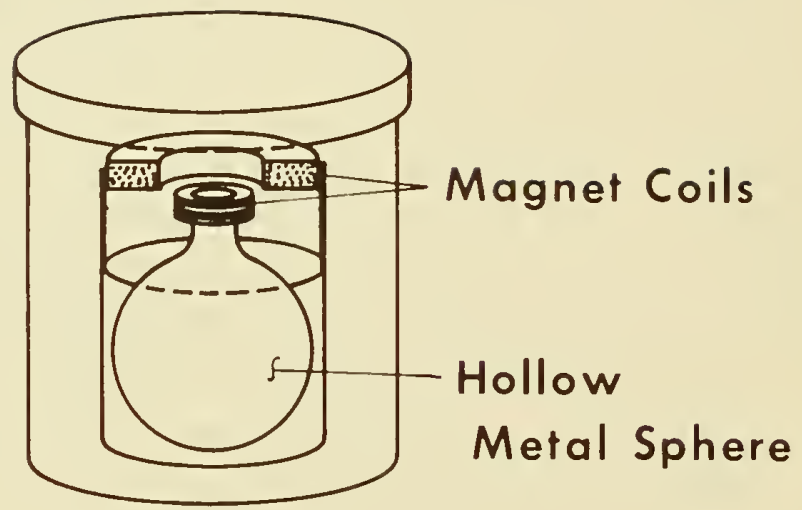

\section{DISPLACEMENT DENSIMETER}

Figure 19. 


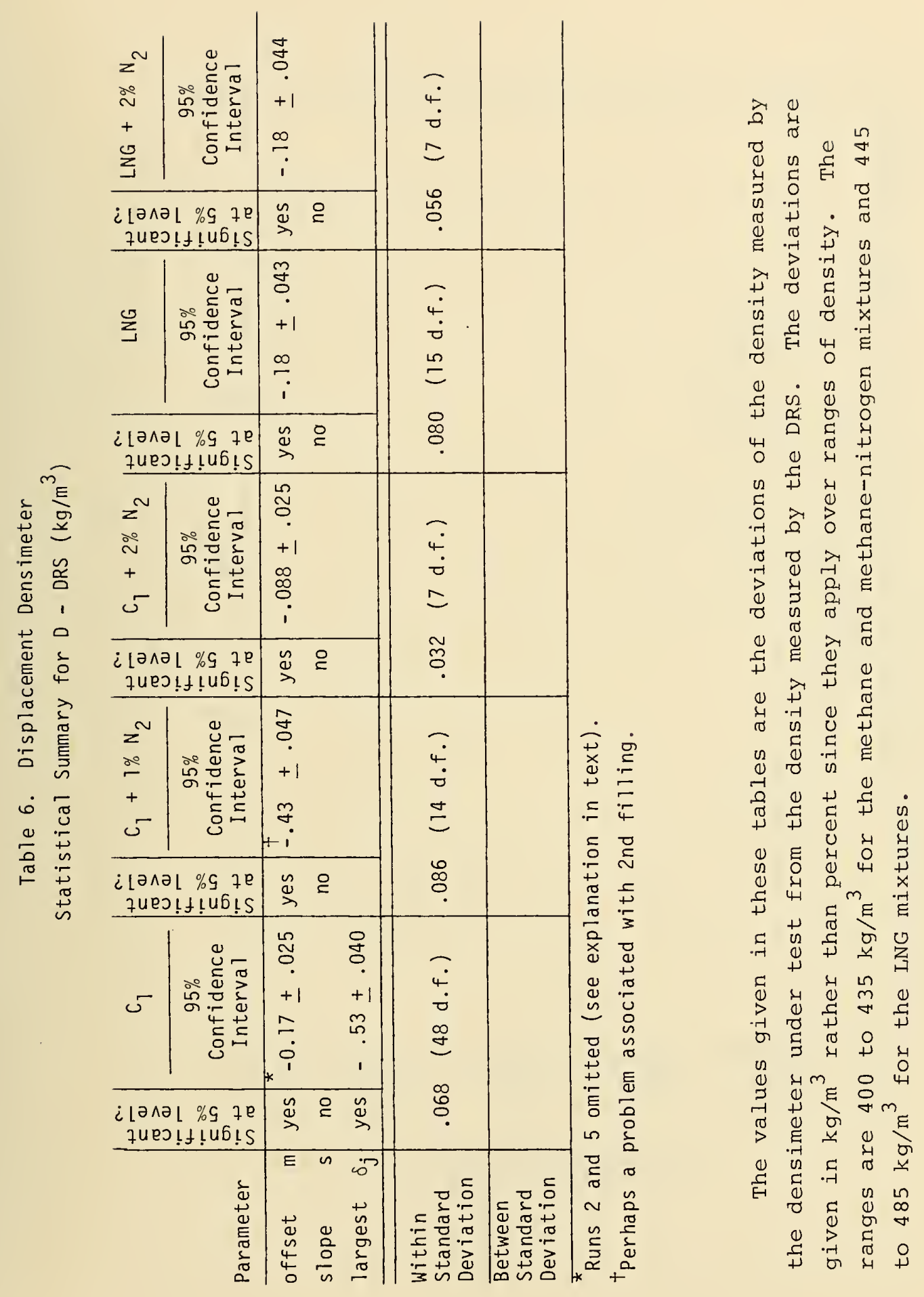




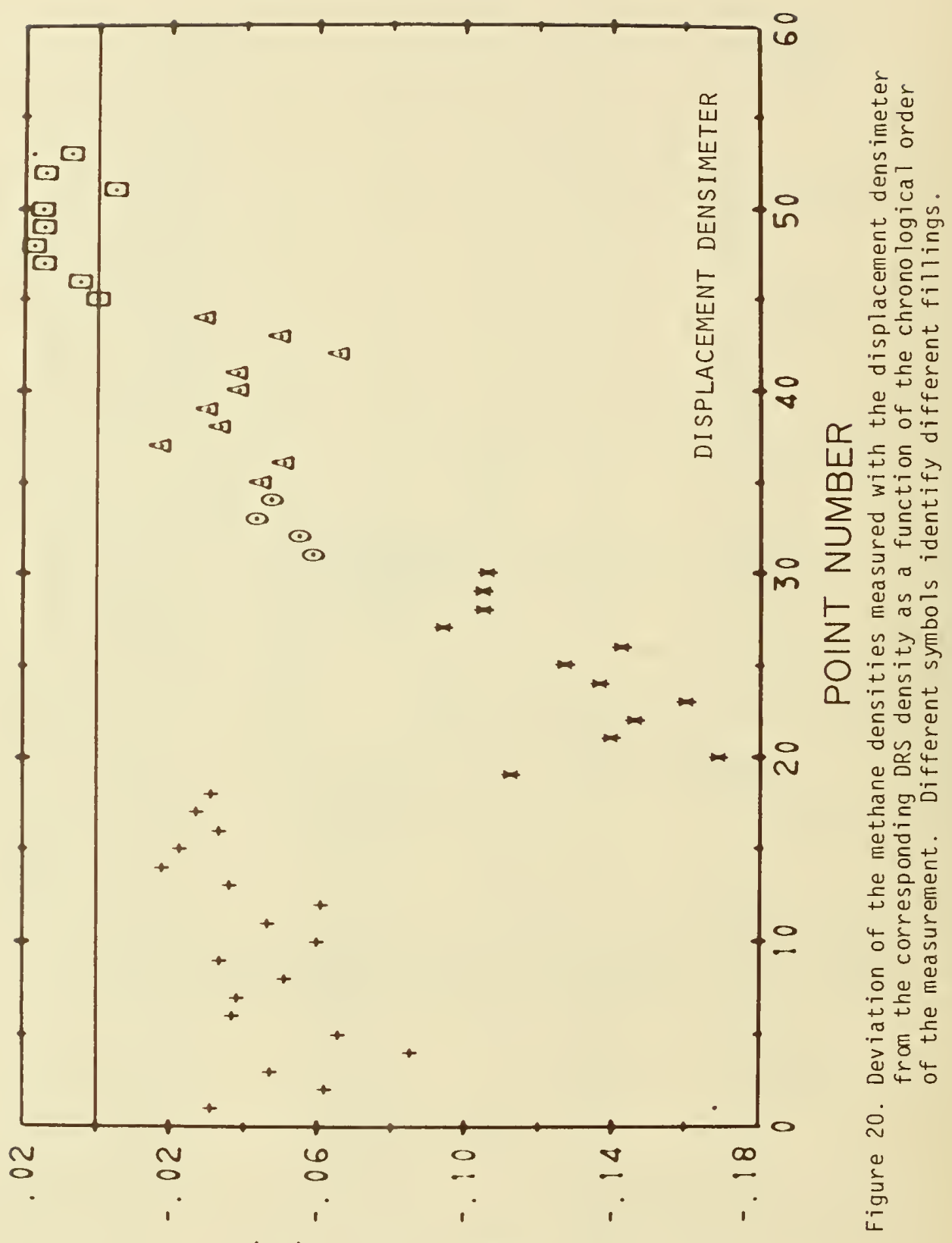

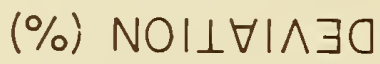




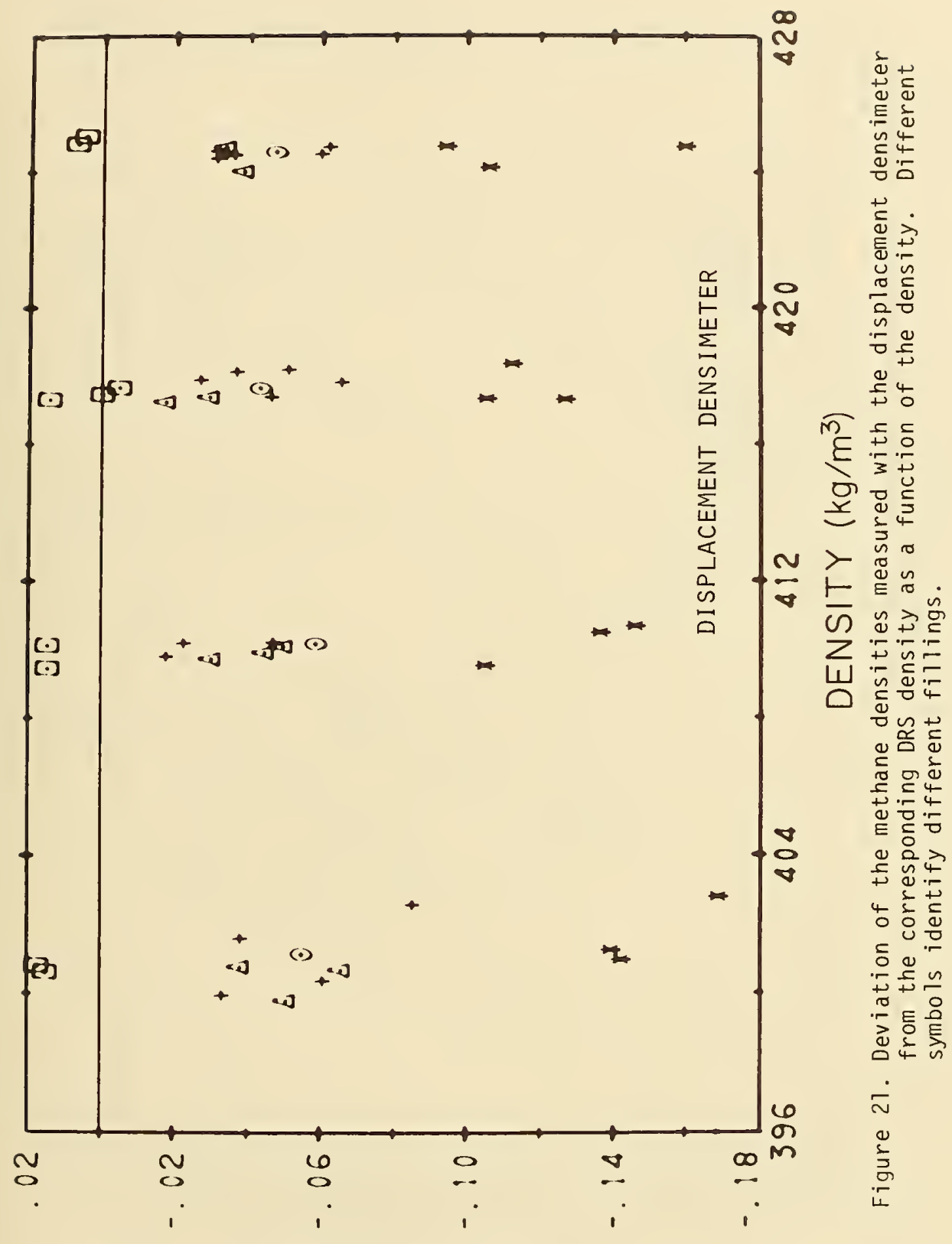

(\%) $N O I \perp \forall I \wedge \exists O$ 


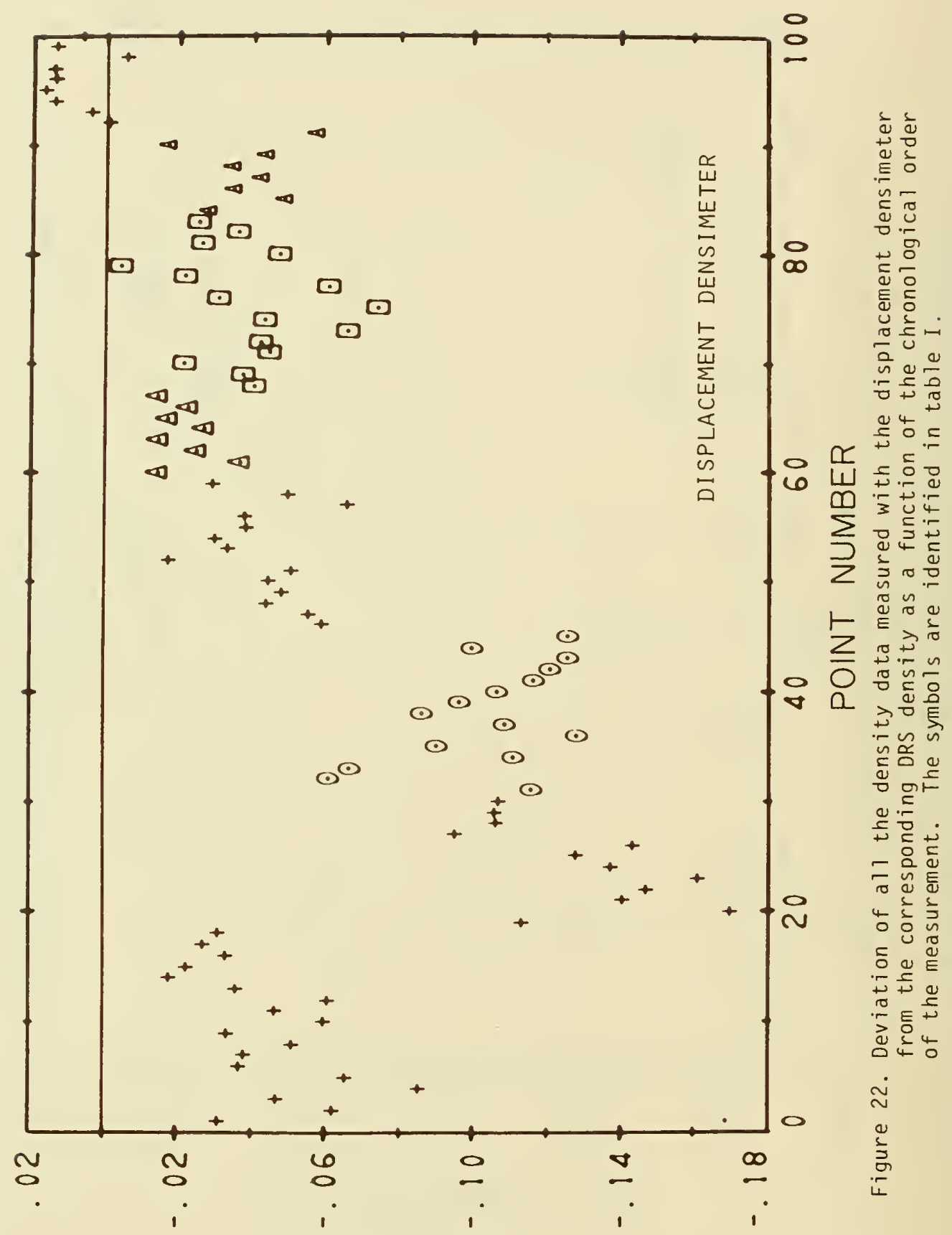

(\%) $N O I \perp \forall \mid \wedge \exists O$ 


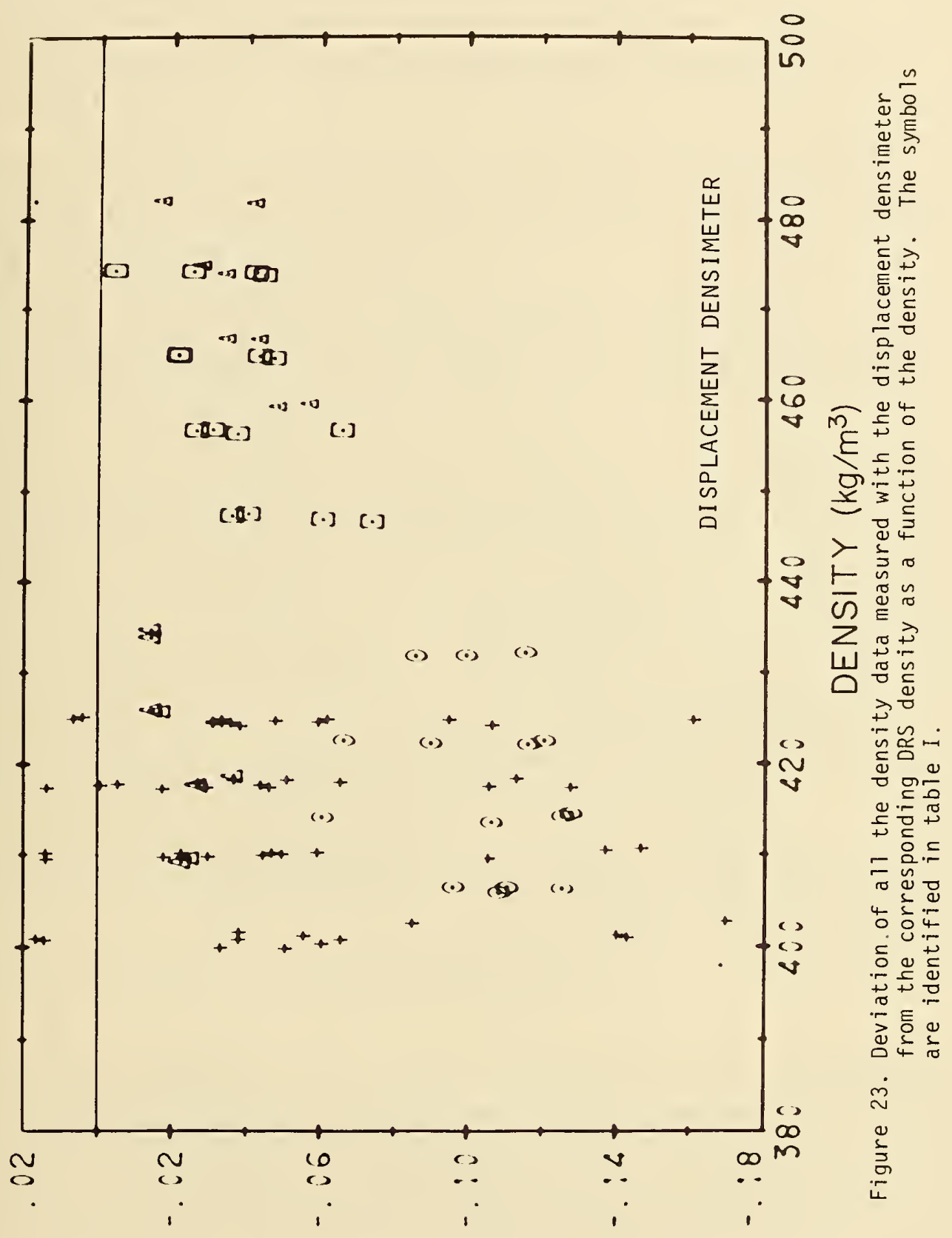

(\%) NOI $\perp \forall I \wedge \exists O$ 


\section{CONCLUSIONS}

This series of tests has shown that from the standpoint of precision, even with the run to run offsets included, all the instruments are suitable for low temperature density measurements on a fluid of known composition. There are, however, some problems with calibration as discussed in section 4. These tests have not established the stability of the various instruments at cryogenic temperatures over a long period of use.

Some of the run-to-run offsets of the vibrating element densimeters may have been the result of variations of the fluid sample level which could not be determined accurately. If the level were too low, the densimeter readings are definitely affected and some offset may still exist at higher fill levels since the acoustic mounting of the vibrating plate densimeter, at least, affects the performance. The calibrations supplied with these densimeters were not suitable for use at cryogenic temperatures.

The measurements on the dielectric cell densimeter support the calculations of Giarratano and Collier [7]. Additional information, probably the composition, must be an input parameter to a density measurement if the measurement accuracy of this instrument is to approach the availabie precision when the fluid composition varies.

The main obstacle to the commercial use of some of these densimeters at low temperature seems to be the lack of a suitable calibration. Also, a means of periodically checking a calibration in or near the field site is desirable. The best method of calibration and field testing would seem to be through the medium of a transfer standard rather than through the properties of a low-temperature fluids which are difficult to analyze in the field and can easily be contaminated. The DRS could serve to calibrate and maintain such transfer standards.

\section{ACKNOWLEDGMENTS}

The authors wish to especially thank Dr. J. C. Holste who contributed heavily to the construction and start up of the density reference system. The authors also wish to thank Janet Donaldson of the NBS Statistical Engineering Laboratory for her recommendations on the method of acquiring data from the automatic balance as well as Patricia Giarratano and Milton Loeb for their contributions to this work.

This project was performed under a grant from the American Gas Association (A.G.A.), on behalf of its membership. 


\section{REFERENCES}

[1] Siegwarth, J. D., Younglove, B. A., and LaBrecque, J. F. LNG density reference system accuracy statement, to be published as an NBS Technical Note.

[2] Goodwin, R. D., The thermodynamic properties of methane, from 90 to $500 \mathrm{k}$ at pressures to 700 bar, Nat. Bur. Stand. (U.S.), Tech Note 653,30 pages (1974).

[3] Haynes, W. M. and Hiza, M. J., Measurements of orthobaric liquid densities of methane, ethane, propane, isobutane and normal butanes, J. Chem. Thermodynamics 9, 179 (1977).

[4] Haynes. W. M. Hiza, M. J., and Frederick, N. V.. A magnetic suspension densimeter for measurements of fluids of cryogenic interest, Instrum. 47, 1237 (1976).

[5] See, for example, Condon, E. U. and Odishaw, H., editors, Handbook of Physics, 4-112. McGraw-Hill Book Co. (1967).

[6] See, for example, Mandell, J., Statistical Analysis of Experiment Data, John Wiley and Sons, Inc. (1964).

[7] Giarratano, P. J. and Collier, R. S., Evaluation of capacitance densitometry by examination of the relationships between density. dielectric, constant, pressure and temperature for ING mixtures, I and EC Process, Design and Development 16, 330 (July 1977). 


\section{APPENDIX I \\ Glossary of Statistical Terms}

Confidence interval: An interval in which the true value of an unknown parameter will lie a certain percentage of the time such an interval is constructed. The percentage used indicates the degree of confidence.

Between standard deviation: A measure of the scatter of the random fluctuations that occurs in the mean from one filling to the next.

Degrees of Freedom: The amount of information available for estimating a standard deviation. It is usually the number of observations less the number of estimated parameters.

Level of confidence: A level of probability at which a stated hypothesis will be rejected on the basis of the data even though the hypotheses is true.

Within standard deviation: A measure of the random scatter observed in data taken under those operating conditions occurring within a filling. 


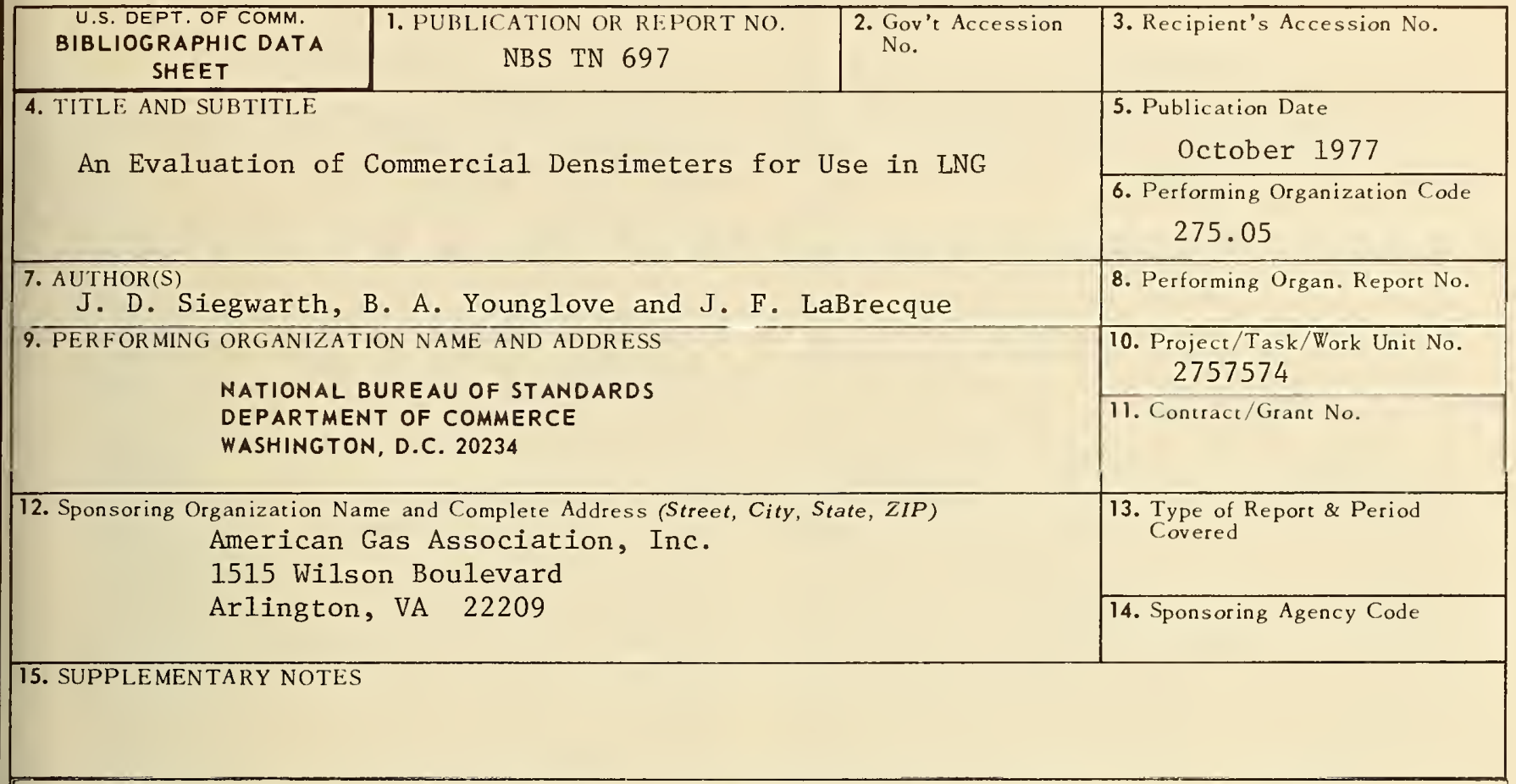

\section{ABSTRACT (A 200-word or less factual summary of most significant information. If document includes a significant} bibliography or literature survey, mention it here.)

The cryogenic fluids density reference system has been used to evaluate three basic types of densimeters: the vibrating element type, the dielectric cell type and the displacement type. These meters were used to measure densities in liquid methane and liquid methane mixtures with ethane, propane, normal butane, and nitrogen. Measurements were made over the density range from 400 to $480 \mathrm{~kg} / \mathrm{m}^{3}$, temperatures from $108 \mathrm{~K}$ to $130 \mathrm{~K}$, and pressures from 1 to 3 bar. A hundred measurements were made at various densities, temperatures, pressures and compositions.

17. KEY WORDS (six to twelve entries; alphabetical order; capitalize only the fitst letter of the first key word unless a proper name; separated by semicolons)

Cryogenic densimeters; density reference system; liquid methane; LNG.

J. D. Siegwarth, B. A. Younglove and J. F. LaBrecque 


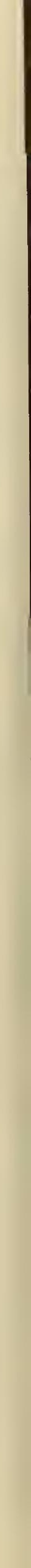




\section{PERIODICALS}

JOURNAL OF RESEARCH--The Journal of Research of the National Bureau of Standards reports NBS research and development in those disciplines of the physical and engineering sciences in which the Bureau is active. These include physics, chemistry, engineering, mathematics, and computer sciences. Papers cover a broad range of subjects, with major emphasis on measurement methodology, and the basic technology underlying standardization. Also included from time to time are survey articles on topics closely related to the Bureau's technical and scientific programs. As a special service to subscribers each issue contains complete citations to all recent NBS publications in NBS and nonNBS media. Issued six times a year. Annual subscription: domestic $\$ 17.00$; foreign $\$ 21.25$. Single copy, $\$ 3.00$ domestic; $\$ 3.75$ foreign.

Note: The Journal was formerly published in two sections: Section A "Physics and Chemistry" and Section B "Mathematical Sciences."

DIMENSIONS/NBS (formerly Technical News Bulletin)This monthly magazine is published to inform scientists, engineers, businessmen, industry, teachers, students, and consumers of the latest advances in science and technology, with primary emphasis on the work at NBS. The magazine highlights and reviews such issues as energy research, fire protection, building technology, metric conversion, pollution abatement, health and safety, and consumer product performance. In addition, it reports the results of Bureau programs in measurement standards and techniques, properties of matter and materials, engineering standards and services, instrumentation, and automatic data processing.

Annual subscription: Domestic, \$12.50; Foreign $\$ 15.65$.

\section{NONPERIODICALS}

Monographs-Major contributions to the technical literature on various subjects related to the Bureau's scientific and technical activities.

Handbooks-Recommended codes of engineering and industrial practice (including safety codes) developed in cooperation with interested industries, professional organizations, and regulatory bodies.

Special Publications-Include proceedings of conferences sponsored by NBS, NBS annual reports, and other special publications appropriate to this grouping such as wall charts, pocket cards, and bibliographies.

Applied Mathematics Series-Mathematical tables, manuals, and studies of special interest to physicists, engineers, chemists, biologists, mathematicians, computer programmers, and others engaged in scientific and technical work.

National Standard Reference Data Series-Provides quantitative data on the physical and chemical properties of materials, compiled from the world's literature and critically evaluated. Developed under a world-wide program coordinated by NBS. Program under authority of National Standard Data Act (Public Law 90-396).
NOTE: At present the principal publication outlet for these data is the Journal of Physical and Chemical Reference Data (JPC'RD) published quarterly for NBS by the American Chemical Society (ACS) and the American Institute of Physics (AIP). Subscriptions, reprints, and supplements available from ACS, 1155 Sixteenth St. N.W., Wash., D.C. 20056.

Building Science Series-Disseminates technical information developed at the Bureau on building materials, components, systems, and whole structures. The series presents research results, test methods, and performance criteria related to the structural and environmental functions and the durability and safety characteristics of building elements and systems. Technical Notes-Studies or reports which are complete in themselves but restrictive in their treatment of a subject. Analogous to monographs but not so comprehensive in scope or definitive in treatment of the subject area. Often serve as a vehicle for final reports of work performed at NBS under the sponsorship of other government agencies. Voluntary Product Standards-Developed under procedures published by the Department of Commerce in Part 10, Title 15, of the Code of Federal Regulations. The purpose of the standards is to establish nationally recognized requirements for products, and to provide all concerned interests with a basis for common understanding of the characteristics of the products. NBS administers this program as a supplement to the activities of the private sector standardizing organizations.

Consumer Information Series-Practical information, based on NBS research and experience, covering areas of interest to the consumer. Easily understandable language and illustrations provide useful background knowledge for shopping in today's technological marketplace.

Order above NBS publications from: Superintendent of Documents, Government Printing Office, Washington, D.C. 20402.

Order following NBS publications-NBSIR's and FIPS from the National Technical Information Services, Springfield, Va. 22161.

Federal Information Processing Standards Publications (FIPS PUB)-Publications in this series collectively constitute the Federal Information Processing Standards Register. Register serves as the official source of information in the Federal Government regarding standards issued by NBS pursuant to the Federal Property and Administrative Services $f_{1}$ ct of 1949 as amended, Public Law 89-306 (79 Stat. 1127), and as implemented by Executive Order 11717 (38 FR 12315, dated May 11, 1973) and Part 6 of Title 15 CFR (Code of Federal Regulations).

NBS Interagency Reports (NBSIR)-A special series of interim or final reports on work performed by NBS for outside sponsors (both government and non-government). In general, initial distribution is handled by the sponsor; public distribution is by the National Technical Information Services (Springfield, Va. 22161) in paper copy or microfiche form.

\section{BIBLIOGRAPHIC SUBSCRIPTION SERVICES}

The following current-awareness and literature-survey bibliographies are issued periodically by the Bureau:

Cryogenic Data Center Current Awareness Service. A literature survey issued biweekly. Annual subscription: Domestic, \$25.00; Foreign, \$30.00.

Liquified Natural Gas. A literature survey issued quarterly. Annual subscription: $\$ 20.00$.
Superconducting Devices and Materials. A literature survey issued quarterly. Annual subscription: $\$ 30.00$. Send subscription orders and remittances for the preceding bibliographic services to National Bureau of Standards, Cryogenic Data Center (275.02) Boulder, Colorado 80302. 

$C O M-293$

Penalty for Private Use. $\$ 300$

SPECIAL FOURTH-CLASS RATE BOOK 